$$
\begin{gathered}
11 \\
\text { WORKING } \\
\text { PAPERS } 2020 \underline{\underline{8}}
\end{gathered}
$$

\title{
THE IMPORTANCE OF DEPOSIT INSURANCE CREDIBILITY
}

Diana Bonfim I João A. C. Santos 



\section{1 \\ WORKING PAPERS 2020}

\section{THE IMPORTANCE OF DEPOSIT INSURANCE CREDIBILITY}

Diana Bonfim | João A. C. Santos

JULY 2020 The analyses, opinions and findings of these papers represent the views of the authors, they are not necessarily those of the Banco de Portugal or the Eurosystem

Please address correspondence to Banco de Portugal, Economics and Research Department Av. Almirante Reis, 71, 1150-012 Lisboa, Portugal Tel.: +351 213130 000, email: estudos@bportugal.pt

BANCO DE PORTUGAL EUROSYSTEM

Lisboa, 2020 • www.bportugal.pt 
Working Papers | Lisboa 2020 • Banco de Portugal Av. Almirante Reis, 71 | 1150-012 Lisboa • www.bportugal.pt • Edition Economics and Research Department • ISBN (online) 978-989-678-739-4 • ISSN (online) 2182-0422 


\title{
The importance of deposit insurance credibility
}

\author{
Diana Bonfim \\ Banco de Portugal \\ Católica Lisbon SBE
}

\author{
João A. C. Santos \\ Federal Reserve Bank of New York \\ Nova SBE
}

July 2020

\begin{abstract}
The success of deposit insurance arrangements at eliminating bank runs is likely closely tied to their credibility. We investigate this hypothesis building on two episodes which tested the insurance protection offered by the Portuguese arrangement in the midst of the country's sovereign debt crisis. Our results show that Portuguese depositors responded to foreign banks' decision to convert their subsidiaries into branches by relocating their deposits into the latter. We find a similar response following the announcement that insured depositors in Cyprus would lose part of their savings. On both instances responses are concentrated on household deposits. Given that foreign banks' branches offer the insurance protection of these banks' home countries, rather than that granted by their host country arrangement, our findings confirm that the credibility of the deposit insurance arrangement is critical for the protection it offers banks against the risk of depositor runs. These results show that sovereign-bank links can be detrimental to financial stability through a novel channel: the credibility of deposit insurance.
\end{abstract}

JEL: G01, G21, G28

Keywords: bank deposits, deposit insurance, bank runs, market discipline.

\footnotetext{
Acknowledgements: The authors thank Rui Albuquerque, Piergiorgio Alessandri, Franklin Allen, Carlo Altavilla, Nuno Alves, Andrada Bilan, Martin Brown, Olivier De Jonghe, Robert DeYoung, João Freitas, Itay Goldstein, Claudia Girardone, Isaac Hacamo, Balint Horvath, Harry Huizinga, Artashes Karapetyan, Catherine Koch, Slawek Kozdras, Luc Laeven, Martien Lamers, Agnese Leonello, Steven Ongena, Teodora Paligorova, Ettore Panetti, Diane Pierret, Jean Charles Rochet, Enrico Sette, André Silva, Helmut Stix, Raluca Roman, Javier Suarez, Razvan Vlahu, Ansgar Walther, and participants at the DNB/EBC/CEPR Conference on Avoiding and Resolving Banking Crises, 2017 EEA, 3rd IWH-FIN-FIRE Workshop on Challenges to Financial Stability, 2018 ASSA/IBEFA, 2018 CEBRA Annual Meeting, 2018 EBA Policy Research Workshop, SAFE Annual Conference on Sustainable Architecture for Finance - Where Are We Now and Where Are We Going, 2019 Biennial IADI Research Conference, and in seminars at Banco de Portugal, University of Zurich, and University of Groningen for insightful comments. Nuno Silva offered an invaluable assistance in the early stages of this project. Bonfim acknowledges grants UID/GES/00407/2013 and PTDC/EGE-OGE/30314/2017 from the Portuguese Foundation for Science and TechnologyFCT. The views stated herein are those of the authors and are not necessarily the views of the Bank of Portugal, the Eurosystem, the Federal Reserve Bank of New York or the Federal Reserve System. E-mail: dbonfim@bportugal.pt; joao.santos@ny.frb.org
} 


\section{Introduction}

Bryant (1980) and Diamond and Dybvig (1983) were critical to our understanding that banks' provision of liquidity services to depositors leaves them exposed to the risk of runs. Since deposit runs can culminate with the failure of the financial system, this led to a search for mechanisms capable of protecting banks from the liquidity shocks induced by deposit runs. Diamond and Dybvig (1986) showed that deposit insurance could offer banks such a protection while still affording them the opportunity to provide liquidity services to depositors. However, the deposit insurance arrangement had to be credible. This explains why the vast majority of deposit schemes are offered by governments (or have their explicit support), as opposed to the private sector, and have detailed information about their coverage and the time it takes for depositors to recover their funds in the event of a bank failure. $^{1}$

In this paper, we investigate the importance of credibility for deposit insurance arrangements. We use data on deposits at banks operating in Portugal, including branches and subsidiaries of foreign banks. We build on two events that occurred during the euro area sovereign debt crisis to investigate depositors' reactions to shocks to deposit insurance credibility.

We first look into depositors' response to sovereign risk. Sovereign risk is important for the credibility of deposit insurance because the insurance fund typically covers only a small fraction of deposits. ${ }^{2}$ Therefore, the reimbursement of depositors at a medium or large bank is only possible if there is a sound sovereign back up of the deposit insurance fund. We consider the decision by some foreign banks operating in Portugal to convert their subsidiaries into branches. While subsidiaries of foreign banks offer their depositors the insurance of the host country, branches offer their depositors the insurance coverage of the country of their parent bank.

The conversion of subsidiaries into branches offers us a good opportunity to investigate the importance of the credibility of the deposit insurance arrangement. They occurred in the midst of the Portuguese sovereign debt crisis, at a time when there was considerable uncertainty about both the country's ability to meet its debt obligations and the stability of its banking system. In contrast, countries of origen of these foreign banks carried very high credit ratings. Also, at the time both the level of insurance coverage and the reimbursement rules in Portugal were the same

1. The uncertainty about the this length of time appears to have played a role in triggering retail depositor runs in the case of Northern Rock, in the U.K. (Goldsmith-Pinkham and Yorulmazer, 2010, Shin, 2009).

2. According to Demirgüç-Kunt et al. (2015), in 2013, the Portuguese deposit insurance fund covered $1 \%$ of total eligible deposits, ranking 17 th (out of 188 countries analyzed) in terms of the generosity of the safety net it offered depositors. 
as in all European Union countries. ${ }^{3}$ However, since Member States were unable to establish an European Deposit Insurance arrangement, the insurance protection of each national arrangement was intimately linked to the ability of the state to honor its obligations with the deposit insurance fund. Further, the public was made aware of the implications of that conversion for deposit insurance coverage. For example, several newspapers noted that Deutsche Bank's decision to convert its subsidiary into a branch would eliminate the bank's exposure to the risk of Portugal and likely give it a wedge in attracting deposits given "that depositing money at the Lisbon branch would be identical to have the money deposited in Germany." ${ }^{4}$

Our second test attempts to ascertain the importance of the credibility of the deposit insurance arrangement by investigating depositors' response to an increase in uncertainty on the level of insurance coverage. In March 2013, it became public that the bailout package the IMF and European authorities granted Cyprus included a requirement to impose losses on all bank deposits, including insured deposits. This information, together with former Eurogroup Chairman Jeroen Dijsselbloem announcement that this could be the template to handle future banking crises, sent shock waves throughout Europe, in particular to countries facing financial difficulties, because it created uncertainty about the coverage offered by their deposit insurance arrangements. We build on that announcement and investigate whether depositors in Portugal responded by moving their deposits into banks that were less susceptible to that uncertainty, i.e. branches of foreign banks from financially sound countries.

Our results show that depositors reacted to the two events. There were no significant aggregate outflows of deposits to foreign countries, unlike what was seen in other countries at the core of the euro area sovereign debt crisis. However, there were significant movements of deposits within the Portuguese banking system in the dates around the two events that we consider. Our results on the conversion of subsidiaries into branches show that this change triggered an increase in deposits at the branches. Our investigation on the aftermath of the Cyprus event also shows an inflow of deposits into foreign branches, in particular those from foreign banks of countries with a high credit rating. Importantly, on both occasions the deposit movements are driven by households rather than corporations. These findings, in particular those that follow the conversion of subsidiaries into branches, are quite robust and do appear to be driven by the events we consider rather than for example a change in banks' deposit rate policies. Our findings suggest that depositors actively monitor banks, especially when there is heightened uncertainty about the

3. Soon after the failure of Lehman Brothers, all Member States adopted a common minimum protection threshold of 100,000 euros and common rules concerning the reimbursement period of depositors. A share of up to 10,000 euros of all deposits covered has to be reimbursed within a maximum period of seven days. The remainder (up to the maximum insured amount) has to be paid within a period of twenty working days.

4. Our translation of a passage in "Deutsche Bank foge ao risco de Portugal," in Jornal Negócios, June 16, 2011. 
protection offered by the deposit insurance arrangement thereby confirming that the credibility of the deposit insurance arrangement is critical for its effectiveness.

Our findings offer a valuable contribution to understand the importance of the credibility of deposit insurance mechanisms. Deposit insurance is widely recognized as an instrumental tool to prevent depositors' bank runs. During the global financial crisis, many governments in advanced economies increased the coverage of their national deposit insurance schemes to avoid panic runs. Our findings suggest that the effectiveness of deposit insurance at insulating banks from runs goes beyond the level of coverage it offers depositors. It also depends critically on the certainty of the protection it offers them, in particular the government's commitment to not alter the rules of the arrangement and the country's ability to honor the arrangement's promises to depositors. ${ }^{5}$

Our findings also offer an important insight for the ongoing debate in the Euro area about the potential implications of countries' fiscal policy responses to the economic effects of the Covid-19 virus outbreak. While the European union took important steps toward establishing a Banking Union following the sovereign debt crisis, it felt short of creating a single European deposit insurance system. As a result, significant changes in the perceived risk of sovereign debt due, for example to large fiscal deficits, can still trigger deposit outflows, adding additional strains to the local banking sector.

There is a sizable empirical literature on deposit insurance. Demirgüç-Kunt and Detagriache (2002) and Demirgüç-Kunt and Huizinga (2004) argue that deposit insurance reduces market discipline based on their study of banks across countries. Alanis et al. (2015), Bennett et al. (2015), Berger and Turk-Ariss (2015), Egan et al. (2017) and lyer and Puri (2012) arrive at a similar conclusion but by investigating the monitoring exercised by uninsured and insured depositors. ${ }^{6}$ Ioannidou and Penas (2010) and Karas et al (2013), in turn, explore the effect of deposit insurance on banks' risk-taking. They argue that banks increase risk after the introduction of deposit insurance in Bolivia and Russia, respectively. Finally, Anginer et al (2014) and Boyle et al (2015) focus on the role of deposit insurance during financial crises. Anginer et al (2014) argues that deposit insurance plays an important stabilizing role during the crisis, while Boyle et al (2015) find that the introduction of deposit insurance only partially mitigates the likelihood of a run during the crisis. ${ }^{7}$

Many of these papers analyze the effect of having or not a deposit insurance mechanism in place. Our evidence on depositors' responses to shocks affecting the credibility of the deposit insurance arrangement suggests one should also take

5. See Demirguc-Kunt and Huizinga (2013), Horvath and Huizinga (2015), Leonello (2018), and Fecht et al., (2019) for discussions on the implications of sovereign debt risk, including those related to deposit insurance protection.

6. Martinez Peria and Schmukler (2001) and Lamers (2015) reach a different conclusion, showing that deposit insurance may not be detrimental to market discipline.

7. Boyle et al (2015) also find that depositors are less likely to run if they have a long relationship with the bank, a finding consistent with evidence uncovered by lyer et al (2016). 
that credibility into account when investigating the effects of deposit insurance. This is likely important in banking crises, particularly when they coincide with a sovereign debt crisis. For, on these instances, governments, which are the ultimate supporters of deposit insurance arrangements, may find themselves unable to meet their obligations with the deposit insurance fund or tempted to change the rules governing the insurance coverage to alleviate the financial burden resulting from bank failures. Our findings on depositors' responses to the conversion of foreign subsidiaries into banks point to the importance that deposit insurance plays in the complex mechanisms underneath the negative feedback loops between banks and sovereigns, as discussed for example by Farhi and Tirole (2016) and Brunnermeier et al (2016).

The rest of the paper is organized as follows. Section 2 discusses our methodology. This section also presents our data sources and characterizes our sample. Section 3 documents depositors' reaction to foreign banks' decision to convert their subsidiaries into branches during the financial crisis in Portugal. Section 4, in turn, shows how depositors in Portugal reacted to the uncertainty created with the announcement following the bailout of Cyprus that going forward insured depositors could incur losses to reduce the burden on taxpayers. Section 5 concludes our paper.

\section{Empirical strategy, data and sample characterization}

\subsection{Empirical strategy}

Our main goal is to understand how depositors value the credibility of deposit insurance schemes. Specifically, we are interested in finding out whether depositors are sensitive to uncertainty about the deposit insurance arrangement's ability to meet its obligations. A challenge in empirically answering this question hinges on the existence of (unexpected) events that allow for a clear identification of that uncertainty. The euro sovereign debt crisis, which hit Portugal in 2010/2011, provides two important events that allow us to understand how depositors respond to changes in the credibility of deposit insurance arrangements.

The first event is the decision of some foreign banks operating in Portugal to transform their subsidiaries into branches during the crisis. This legal change has a crucial implication for depositors' protection. After these changes, deposits are covered by the deposit insurance arrangements of the home country of these banks rather than by the Portuguese deposit guarantee scheme (Dell'Ariccia and Marquez, 2010, Calzolari et al., 2019). Deposit insurance arrangements usually operate with a fund that accounts for only a small portion of the deposits they insure and rely on explicit support from the government to guarantee their obligations in case one or more banks default. To the extent that depositors value the credibility of the deposit insurance arrangement, the uncertainty about the Portuguese deposit insurance arrangement's ability to fully meet its obligations by virtue of the 
country's sovereign debt crisis, should lead deposits to flow into the newly created branches and away from domestic banks. Further, we would expect this effect to be more pronounced among insured deposits, and to impact more financially weaker domestic banks.

While one may worry about the endogeneity of foreign banks' decision to convert their subsidiaries into subsidiaries, the second event we consider is exogenous to Portugal. On March 16th 2013, the IMF and European authorities agreed on a bailout package for Cyprus, after a request for financial assistance. One of the conditions defined in that package implied losses on all bank deposits, including those that were insured by the Cypriot deposit guarantee scheme (Brown et al, 2016). More precisely, deposits above 100,000 euros would be subject to a haircut of $9.9 \%$, while deposits below that threshold, which were in theory fully insured, would face a loss of $6.7 \%$. That announcement affected the credibility not only of the Cypriot deposit insurance arrangement, but also the creditability of deposit insurance arrangements in the European countries under distress. ${ }^{8}$ Given the dramatic shock waves that the announcement triggered throughout Europe, the decision was reversed nine days later (March 25th). We test whether depositors in Portugal reacted to these events in Cyprus by moving their deposits to banks with more reliable deposit insurance coverage, including branches of foreign banks operating in Portugal.

We estimate the following model of bank deposits to investigate the first event: conversion of subsidiaries of foreign banks operating in Portugal into branches.

$$
y_{i t}=\alpha_{0}+\alpha_{t}+\alpha_{i}+\beta_{1} \text { branch }_{i t}+\gamma X_{i t-1}
$$

where $y_{i t}$ refers to the $\log$ of deposits at the end of the month $(\log ($ deposits $))$ or, in some specifications, the monthly growth rate of deposits (gr_rate). We estimate that model for the total deposits of the non-financial private sector. We also estimate it separately for households' and firms' deposits. $\alpha_{t}$ and $\alpha_{i}$ are time and bank fixed effects, respectively. The main coefficient of interest is $\beta_{1}$. When we estimate model 1 without bank fixed effects, $\beta_{1}$ captures the effect on deposits of being a branch relative to banks and subsidiaries. When we include bank fixed effects, $\beta_{1}$ captures the effect on deposits from becoming a branch.

$X_{i t-1}$ is a vector of lagged bank characteristics. It includes proxies for bank performance such as non-performing loans as a percentage of total credit, and net profits as a percentage of total assets. It also includes a proxy for the bank's liquidity, measured by liquid assets as a percentage of interbank liabilities, and a proxy for its financial condition measured by the bank's book equity as a percentage

8. "The worst-case scenario under a plan with a haircut is that the plan triggers a run on banks not just in Cyprus (that appears to already be happening) but in other vulnerable countries like Spain and Italy as customers worry that the E.U. will try to impose similar conditions there. That would exacerbate an already bad situation as it would increase bank shortfalls; fewer deposits, after all, mean a worse deposit-to-liability ratio." Washington Post, March 18, 2013 
of total assets. In addition, we control for the bank's loan to deposit ratio, and for the interest rate the bank offers its depositors.

In the second exercise, where we explore the announcement that insured deposits in Cyprus would be subject to a haircut as part of the bailout package arranged by the IMF and the European authorities, we consider the following model of deposits:

$$
y_{i t}=\alpha_{0}+\alpha_{t}+\beta_{1} \text { Cyprus }_{t}+\text { stype }_{i t}+\gamma X_{i t-1}
$$

where, as in model $1, y_{i t}$ refers to the log of deposits at the end of the month or the monthly growth rate of deposits. As before, we estimate model 2 for the total deposits and separately for households' and firms' deposits. The key variable of interest in that model is Cyprus, a dummy variable that takes the value one in March and April of 2013. Recall that the initial announcement on insured deposit haircuts occurred on March 16th and the reversal of this decision was communicated on March 25th. We include in Cyprus the month of April, in addition to March, to account for the possibility that some depositors might have been skeptical about the reversal announcement at the end of March. In this specification we do not use bank fixed effects because we are interested in capturing the cross-sectional variation, rather than the within bank variation. Cyprus will tell us whether depositors moved their deposits out of the universe of banks operating in Portugal during the period of increased uncertainty about deposit insurance triggered by that announcement.

As in our first exercise, we estimate model 2 controlling for the set of bankspecific factors $X_{i t-1}$. In addition, we control for the type ${ }_{i t}$ of institution, i.e., whether the bank is domestic or foreign and, in that case, if it operates as a branch or a subsidiary.

Further, under the first event we expect depositors to migrate to the newly established branches of foreign banks because they are not exposed to the potential uncertainty of the Portuguese insurance arrangement arising from the country's sovereign crisis. Following this assertion, we expand model 2 to include the interaction between Cyprus and the type $e_{i t}$ of institution to investigate whether the behavior of depositors following the Cyprus announcement was heterogeneous across different types of institutions. We are particularly interested in finding out whether the behavior of depositors in foreign branches was different given the perceived additional credibility of deposit insurance arrangements covering these branches.

Lastly, we expand model 2 to include the interaction between Cyprus and our set of bank controls, $X_{i t-1}$, to investigate whether depositors reacted differently depending on the observable characteristics of their banks. We are particularly interested in finding out whether depositors of financially weaker banks or those of poor performing banks, which were more exposed to the uncertainty about the credibility of the Portuguese deposit insurance arrangement, responded more following the Cyprus announcement on prospective haircuts on insured deposits. 


\subsection{Data sources}

The data for this project comes primarily from two sources. We use the monthly Monetary and Financial Statistics of Banco de Portugal to collect monthly data on deposits between March 2007 and December 2013. We also use this data source to collect information on households' and firms' deposits. This breakdown is important because as we discussed in the introduction households' deposits are more likely to be insured than firms' deposits and therefore more likely to respond to changes in the credibility of the deposit insurance arrangement.

We use banks' monthly supervisory reports to get data on the additional banklevel variables we use in our investigation of deposits, including net profits, nonperforming loans, liquid assets, total loans, interbank liabilities equity, and total assets. We also use supervisory reports to gather information about the type of the financial institution. We classify institutions as domestic banks, foreign subsidiaries and foreign branches. This classification is important for our investigation because as we noted above deposits held by foreign branches are guaranteed by the Portuguese deposit insurance arrangement while those of foreign subsidiaries are guaranteed by the home country of the parent bank.

\subsection{Sample characterization}

Table 1 presents summary statistics for the variables we use in our estimations. Panel A presents results for all of the banks in our sample. Deposits in the banking system grew, but at a small rate between 2007 and 2013. Banks paid higher deposit rates to households than firms: The average interest rate on deposits was $2.85 \%$ for households and $2.46 \%$ for firms. Profitability was fairly weak: the average return on assets was $0.55 \%$ and the net interest margin was $2.97 \%$. Non-performing loans were a driving factor of banks' weak profitability: the average non-performing loan ratio was $7.34 \%$ ( $3.31 \%$ for the median bank).

The median loan-to-deposit ratio was $149.8 \%$, showing that Portuguese banks relied substantially on funding from wholesale debt markets (and also from central bank funding, in the last years of the sample). There is a large variation in this ratio, reflecting substantial heterogeneity in business models and funding strategies. The liquidity ratio, defined as liquid assets as a percentage of interbank liabilities, was on average $216.4 \%$, showing that most banks had sizeable liquidity buffers to face short term funding needs. Lastly, banks' book equity over total assets was on average $7.34 \%$. For the subsample that excludes foreign branches, banks' regulatory capital ratio was on average $15.45 \% .{ }^{9}$

Panel B reports summary statistics for the three types of institutions that we analyze: domestic banks, foreign subsidiaries and foreign branches. There were 53

9. Foreign branches from EU countries are not in this sub-sample because they are exempt from meeting capital requirements in the host countries. 
banks at the beginning of our sample period of which 15 were branches and 11 were subsidiaries of foreign banks operating at the time in Portugal. Domestic banks account fore more than half of the observations in our sample $(54 \%)$. Within the group of foreign banks, $59 \%$ operate in Portugal with branches and the remaining $41 \%$ use subsidiaries.

Foreign branches are smaller than domestic banks and foreign subsidiaries. Deposit growth was larger for foreign banks than domestic banks. This happened even though domestic banks offered higher interest rates on deposits. Interestingly, while foreign branches attracted more corporate deposits, foreign subsidiaries were able to attract more household deposits, consistent with our prior that household deposits are more sensitive to the credibility of the home-country deposit insurance arrangement.

With regards to the other bank characteristics, the results are rather mixed. None of the three types of banks shows up as having consistently better or worse performance. Domestic banks have the lowest loan to deposit ratios and the highest liquidity ratios; foreign branches have the lowest non-performing loan ratios but also the smallest capital-to-assets ratios. Lastly, foreign subsidiaries have the highest profitability indicators.

2.3.1. Determinants of banks' deposits. To get a sense of the determinants of banks' deposits, we report in Table 2 the results of the following model:

$$
y_{i t}=\alpha_{0}+\gamma X_{i t-1}
$$

where $X_{t-1}$ is a set of bank-specific factors that are likely to drive banks' deposits. Standard errors are clustered at the bank level. In Columns (1) to (3), the dependent variable is the growth rate of deposits and we include time fixed effects. This analysis tells us how does deposit growth varies across banks, depending on their characteristics. Column (1) investigates total deposits, while Columns (2) and (3) look at household deposits and corporate deposits, respectively. In Columns (4) to (6), the dependent variable is the logarithm of deposits, and we include bank fixed effects on top of the time fixed effects. This analysis explores within bank variation and tells us how deposits grow within a bank when its characteristics change.

The growth rate of deposits is higher for better capitalized banks (Columns 1-3). In a period of heightened uncertainty, it is interesting to find that depositors appear to discriminate between banks based on their capital ratios. More profitable banks also record stronger deposit growth, further supporting this hypothesis. Household deposits increase less in banks with higher loan-to-deposit ratios, while the opposite is true for corporate deposits, possibly because corporations take out loans and make their deposits in the same bank. Household deposits increase more in banks that offered higher deposit rates. In contrast, firm deposits increase less in banks with higher rates. The latter result may appear counterintuitive, but is consistent with the idea that there is bundling between corporate deposits and loans, in which case deposit rates will play a lesser role in firms' deposit decisions. 
Some of the insights from the cross section analysis (Columns 1-3) continue to hold in the within-bank analysis (Columns 4-6). For example, households prefer banks that offer higher interest rates and they also increase their deposits in response to an increase in banks' deposit rates. Similarly, households prefer well capitalized banks and respond positively to an increase in their banks' capital ratios. Also consistent with our previous finding that corporations prefer banks with higher loan-to-deposit ratios, we see that corporate deposits increase when the bank's loan-to-deposit goes up. There are also some differences between the two analyzes. For instance, depositors allocate more deposits to banks that have higher profits, but they do not seem respond to an improvement in their banks' profits. Similarly, depositors do not show a preference for larger or smaller banks, but they increase their deposits in banks that are growing. Of course, these relationships are not causal, but allow us to have an understanding of those bank characteristics that correlate with deposits.

\section{Depositors' response to sovereign risk}

The results of the previous section show that depositors are sensitive not only to banks' deposit rates, but also to observable bank characteristics related to their financial condition. In a world where deposit insurance was universal, unlimited and fully credible, the latter effects would be surprising. However, insurance is limited 100,000 euros, giving depositors' incentives to select financially safe banks. It is not universal and local government support is critical for the credibility of the country's insurance arrangement (deposit insurance funds account for only a fraction of the insured deposits). Therefore, uncertainty about that support may lead depositors to move their savings to safer banks or outside the national banking system.

The European Union harmonized a set of features of its member countries' insurance arrangements (i.e. level of insurance coverage, time required to reimburse insured deposits in the event of a default), but it felt short of creating a single European deposit insurance system. As a result, the insurance protection depositors enjoy in each member country remained dependent on the country's ability to support its insurance fund in the event of bank failures. During the euro area sovereign debt crisis, Portugal was in the spotlight with questions as to whether the country would be able to fully meet its financial obligations. In the Spring of 2011 the country had to request international financial assistance. During this turbulent period, depositors might have been worried about the safety of their deposits because of a potential inability of the country to meet the commitments of its deposit insurance arrangement.

Identifying an effect from uncertainty about the credibility of the deposit insurance arrangement poses significant challenges. For example, depositors could split their deposits across banks to diversify their risk exposure to banks, in case of failure. However, this could also be driven by an incentive to increase their insurance coverage because under the Portuguese deposit insurance arrangement, 
the coverage limit is 100,000 euros per depositor in each bank. Similarly, depositors could move their savings towards branches of foreign banks operating in Portugal to benefit from the insurance protection of these banks' home country. ${ }^{10}$ However, these branches might be financially sounder than other banks and depositors are simply reacting to that difference.

We capitalize on two foreign banks operating in Portugal that switched their subsidiaries into branches during the sovereign debt crisis to deal with these identification challenges. ${ }^{11}$ If depositors were concerned with the credibility of the domestic insurance arrangement then we should see deposits flowing into these newly converted branches (and away from domestic banks, particularly those in more acute distress, i.e., where the likelihood of involvement of the deposit guarantee scheme could be higher). Importantly, these switches occurred at different dates during the sovereign debt crisis and there was no change in the intrinsic soundness of the parent banks of those branches. Further, while the Portuguese debt had a junk rating in the main three agencies at the time, the home countries of the banks that changed the legal status of their subsidiaries in Portugal were at the top of the rating scale.

Despite the magnitude of the crisis, Portuguese deposits did not fall as they did in Greece (Figure 1). However, Portuguese depositors appear to have responded to the change in the legal status of foreign subsidiaries into branches (Figure 2). Subsidiaries that converted to branches were able to attract more deposits than the other banks in the twelve-month period after they changed their legal status. The effect was faster for households, with the increase concentrated around the moment of conversion. These changes do not appear to have been driven by an attempt to gain market share by offering higher deposit rates (Figure 3). In fact, the deposit rate offered by the newly converted branches was significantly below that of the other banks during most of the period.

We investigate the impact of the conversion of subsidiaries into branches on deposits by estimating model 1 . We start by investigating whether there are significant differences from being a branch or a subsidiary i.e. do branches and/or subsidiaries consistently attract more deposits relative to domestic banks? To that end, we estimate model 1 where the dependent variable is the monthly growth rate of deposits (total, household and corporate) and we include time fixed effects. The results of this exercise, which are reported in columns (1)-(3) of Table 3, show that depositors do not have a preference for either foreign branches or subsidiaries (relative to domestic banks) during our sample period. The coefficient associated with being a branch is never statistically significant. The coefficient associated with being a subsidiary is significant for total deposits, but only marginally. This shows

10. Recall that deposits held at foreign branches are insured by the home country deposit insurance scheme, while deposits held at foreign subsidiaries are guaranteed domestically.

11. For confidentiality reasons we cannot identify these banks or the separate effects associated with each of them. 
that depositors do not show a structural preference for branches or subsidiaries during the sample period, after controlling for other bank characteristics.

More important for our purposes, however, is to understand what happens when a foreign subsidiary changes its status and becomes a branch. To investigate the impact of this change in legal status, we reestimate model 1 but this time with bank and time fixed effects. Using bank fixed effects allows us to capture the effect on deposits from becoming a branch. Given that now we are looking into within bank variation, we use as our dependent variable the level of deposits, rather than its growth rate. In other words, we examine if deposits grow after a foreign subsidiary becomes a branch, rather than if the growth rate of deposits accelerates after that conversion.

The results of this investigation, which are reported in columns (4)-(6) of Table 3 , show that when foreign subsidiaries become branches there is a significant inflow of deposits. This finding holds after we control for time-varying bank characteristics and deposit rates as well as time-fixed effects. Also, the deposit inflow occurs both in the household- and corporate-segments of the market.

According to the 2013 Household Finance and Consumption Survey, the median deposits of households in Portugal are 11,100 euros. Even for the highest decile of wealth, the median deposits are 24,700 euros. In contrast, based on data from the Central Balance Sheet managed by Portuguese banks, the average amount held in cash and deposits by corporations in the same period was 81,800 euros. Thus, while a small portion of firms' deposits might benefit from the protection offered by deposit insurance, the vast majority of Portuguese household deposits are covered by deposit insurance. As such, household deposits are likely to be more sensitive to changes in the perceived credibility of deposit insurance. To investigate this hypothesis, we present in column (7) one additional specification, where we pool the data on households and firms. In this pooled dataset, we interact the effect of becoming a branch with two dummy variables that identify households and firms. The results show that the changes are driven by households, the depositors that stand to benefit the most from the additional protection provided by foreign countries' insurance arrangements over the Portuguese insurance scheme.

Our evidence on the inflow of deposits into newly converted foreign branches suggests that depositors in Portugal were concerned with the credibility of the local deposit insurance arrangement owed to the country's sovereign debt crisis. Our evidence that this inflow was more prevalent among households than firms adds support to that assertion. While a very large fraction of household deposits are covered by the deposit guarantee arrangement, only a small portion of corporate deposits is entirely covered by the 100,000 euros limit. As such, households are expected to be more sensitive to changes in the perceived credibility of deposit insurance protection. 


\subsection{Robustness tests}

3.1.1. Using different control groups. In this section, we report the results of a set of robustness tests. The results we presented thus far compare the evolution of deposits in foreign subsidiaries that converted to branches with deposits in all of the other banks operating in Portugal. A potential concern with those results is that foreign banks might have different business models and strategies or they may cater different customers or geographies.

To address that concern, we present in Table 4 the results for equation 1 , but exploring other control groups. In columns (1)-(3) we assess the effects of becoming a branch compared to other foreign banks operating in Portugal at the same time. If depositors have a preference for foreign banks, then including domestic banks in the control group could confound the results. When we compare what happens to deposits after foreign subsidiaries become branches to what happens to deposits at the same time in the remaining foreign banks, we still see a consistent and significant effect. In other words, depositors do not migrate towards foreign banks operating in Portugal (either through a subsidiary or a branch) during that period of heighten uncertainty; instead they choose specifically to allocate their savings to the newly formed foreign branches.

In columns (4)-(6) we consider an even stricter control group: the foreign banks that were operating in the country through subsidiaries. In this case, we compare what happened to deposits after some foreign banks changed their status from subsidiaries to branches with others that were operating with subsidiaries to start with and did not change their legal status during the same period. This should be the closest matching possible between treatment and control groups. Even though the sample is now much smaller, relying only on 5 to 7 banks, we still find similar results. Depositors reallocate more of their savings to foreign banks that change their status than to those that continue to operate as subsidiaries and thus continue being insured by the domestic deposit insurance arrangement.

For completeness, we compare foreign subsidiaries that become branches with other branches of foreign banks operating in the country (columns 7-9). A potential drawback of this exercise is that not all of the branches in the control group are held by banking groups with headquarters in the top-rated countries of the euro area. For example, some of them are branches of banks whose home country was also strongly affected by the euro area sovereign debt crisis, namely Spanish banks. Nonetheless, it is reassuring to see that newly converted branches enjoy an inflow of deposits. Further, we continue to find that this inflow is stronger for household deposits.

Another potential concern with our findings is that the subsidiaries that became branches are fairly small. Thus, it might seem unreasonable to compare the evolution of deposits at these institutions to that at larger banks. For once, depositors may believe the largest banks are too-big-to fail and assume their 
deposits would be safe regardless of what happens to the bank. ${ }^{12}$ Further, one of the largest banks operating in Portugal is a foreign subsidiary, which might confound the effects. ${ }^{13}$ To reduce concerns with the presence of large banks in our control group, in columns (10)-(12) we report the results after we exclude the largest 5 banks from the control group. Our findings on deposits associated with the conversion of foreign subsidiaries into branches continue to hold.

Finally, in columns (13)-(15) we adopt the opposite approach and compare the evolution of deposits in the subsidiaries that became branches with deposits in these 5 largest banks. We still find a robust effect on the reaction of depositors who showed a preference for the new branches even over the banks that are likely perceived to be too-big-to fail. This further supports the argument that our results are driven by concerns that depositors have about the credibility of the local deposit insurance arrangement. Given that the large banks would be bailed out by the same sovereign that backs up the deposit insurance fund, our results suggest that depositors still have a preference for banks which offer deposit insurance backed by countries immune to the sovereign debt crisis.

3.1.2. Using different estimation approaches. The next set of robustness considers different estimation approaches. The results of these tests are reported in Table 5 . In columns (1)-(3), we report the results when we use bank*time fixed effects instead of controlling separately for bank unobserved heterogeneity and for time trends. Our findings continue to hold for total and household deposits, but in this stricter approach they are no longer statistically significant for corporate deposits. This means that when we consider the variation in deposits for the foreign subsidiaries that become branches within the year in which that change occurred, the results are driven by household deposits. This is consistent with our expectations that households are more sensitive to changes in the credibility of the deposit insurance arrangement.

In columns (4)-(6) we adopt a differences-in-differences specification to identify the effect of subsidiaries' conversion into branches. Instead of using bank fixed effects to capture within bank variation when this change occurs, we estimate the following model:

$$
y_{i t}=\alpha_{0}+\alpha_{t}+\beta_{1} \text { After } * \text { branch }_{i t}+\beta_{2} \text { branch }_{i t}+\gamma X_{i t-1}
$$

In this model, $\beta_{1}$ captures the impact on deposits from subsidiary conversion into a branch. The results are entirely consistent with our baseline findings. We find a positive and significant effect across all specifications for total deposits. Further, in Table 1A in the Appendix we report the differences-in-differences results for all of

12. Indeed, when of the largest banks failed after our sample period, uninsured depositors were spared from losses, unlike what happened to other more junior debtholders (Beck et al., 2020).

13. This particular subsidiary is not among the subsidiaries that convert into branches. 
the alternative control groups we consider in Table 4. The results remain consistent and are generally stronger for household deposits.

Summing up, we find that depositors responded to the change in the legal status of foreign subsidiaries into branches, transferring their savings to the latter. Given that, for depositors, the main implication of this shift is a change in the sovereign responsible for supporting the deposit insurance arrangement, these results suggest that the credibility of the deposit insurance scheme affects depositors' behavior. Our evidence that households respond more aggressively than corporations to that change in legal status adds support to our assertion on the importance of the credibility of the deposit insurance arrangement. The reason is that households stand to benefit more from a credible deposit insurance because, in contrast to corporations, the vast majority of their deposits are insured.

\section{Depositors' response to uncertainty in insurance coverage}

The events in Cyprus in the Spring of 2013 provide us with an alternative opportunity to investigate the value of the credibility underlying deposit insurance. In the previous section, our tests built on the uncertainty about Portugal's ability to step in and meet its obligations to the country's deposit insurance arrangement in the event of bank failures due to the country's sovereign debt crisis. In this section, our tests build instead on the uncertainty created by the announcement that insured depositors in Cyprus would be subject to a haircut on their deposits as part of the bailout program extended to the country.

In March 16th 2013, the IMF and European authorities agreed on a bailout package for Cyprus, after a request for financial assistance. One of the conditions defined in the bailout package implied losses on all bank deposits, including insured deposits. More precisely, deposits above 100,000 euros would have a haircut of $9.9 \%$, while deposits below that threshold, which were in theory fully insured, would face a loss of $6.7 \%$. This announcement affected the credibility of deposit insurance, not only in Cyprus, but also in other European countries under distress. Uncertainty peaked after the announcement, most notably after the former Eurogroup Chairman Jeroen Dijsselbloem stated that this could be the template to handle future crises in Europe. ${ }^{14}$ Given the dramatic shock waves the announcement created throughout Europe, the decision was reversed on March 25th.

Notwithstanding that reversal, the episode might have had an impact on depositors, in particular those in countries like Portugal that were most impacted by the sovereign debt crisis, by affecting their trust on the coverage guaranteed by the deposit insurance arrangement. This is the hypothesis we investigate in

14. "Eurogroup Chairman Jeroen Dijsselbloem caused uproar in financial markets by saying in an interview with Reuters and the Financial Times that the Cyprus solution gave a flavor of how Europe would handle future bank crises, by making banks solve their own problems rather than using European taxpayers money.", Reuters, Q A-What next after Cyprus bailout?, 26 March 2013. 
this section. Crucially for this exercise, the direct links between the Portugal and Cyprus are negligible, both economically and financially. Any reaction is thus more likely related to changes in trust on the deposit insurance scheme than to potential contagion spillovers coming from the bailout package granted to Cyprus.

The results of our investigation of model 2, which allows us to test whether depositors in Portugal reacted to the events in Cyprus, are reported in Table 6 . This table follows a similar structure to Table 3, i.e. Columns (1)-(3) report the results for the growth rate of deposits estimated with time fixed effects while Columns (4)-(6) report the results for the log level of deposits estimated with bank and time fixed effects.

Looking at the first three models of Table, 6 we see a significant reaction only among household depositors around the event window (the two months after the announcement of the bailout package in Cyprus). While that reaction is in line with the hypothesis that the results are related to the credibility of deposit insurance, because the fraction of insured corporate deposits is much lower than that of households, it is only marginally significant. Further, when we look at the change in the level of deposits within banks (Columns (4) to (6)) we see no statistically significant effects in response to the events in Cyprus. This absence of an overall effect in deposits is not surprising because it is in line with the evidence we unveiled around the time Portugal sought out and received its bailout package.

That, however, does not imply that depositors did not respond to the uncertainty created by the Cyprus announcement by moving their deposits among the banks operating in Portugal. In particular, if that announcement introduced some uncertainty about the insurance protection provided by the Portuguese arrangement then in line with the evidence we unveiled in the previous section depositors might have transferred their savings into branches of foreign banks operating in Portugal in particular those of banks from financially sound countries.

To investigate this possibility, we begin by expanding model 2 to include the interaction between the event dummy with a dummy that captures if a bank is foreign. The results of this exercise, which are reported in Columns (1)-(3) of Table 7 , show that the interaction term, Cyprus*Foreign, is not statistically significant in any of the models. This suggests that depositors in Portugal did not respond to the events in Cyprus by moving their deposits into foreign banks in the country. It is possible that the absence of an effect in this exercise derives from us combining in the set of foreign banks both branches and subsidiaries. Recall that the latter offer depositors the same insurance protection as do Portuguese banks.

To ascertain that possibility, we split our foreign dummy into two separate dummy variables to isolate the subsidiaries and branches of foreign banks operating in Portugal. The results of this exercise, which are reported in Columns (4)-(6), do not show evidence of a migration of deposits of branches of foreign banks. Importantly, however, when we go a step further and isolate the deposits at those branches that resulted from the conversion of subsidiaries in 2011 (almost two years before the events in Cyprus) then we see a significant effect (Columns (7)-(9)). This distinction is likely related to the nationality of the branches. As we mentioned in 
the previous section, the converted branches belong to banks domiciled in euro area from countries with the highest credit ratings. In contrast, most of the remaining branches operating in Portugal are Spanish-owned. Given that in 2013 the Spanish banking system was also going through a crisis, the effects are naturally weaker when we consider all foreign branches together.

To understand the origin of the deposits that reacted to the Cyprus event, we expand model 2 to include the interaction of the dummy variable for the Cyprus event with bank characteristics. The results of this exercise are reported in Table 8. As expected, they are concentrated in household deposits. Further, we see that household depositors exit predominately weaker performing banks, i.e. those with lower ROA and lower net interest margins.

In conclusion, the results we unveiled in this section showing that Portuguese households responded to the uncertainty on deposit insurance coverage following the events in Cyprus are in line with the findings we unveiled in the previous section on depositors' reaction to foreign subsidiaries' conversion into branches. On both instances, depositors' responses are consistent with them seeking more certainty on the insurance coverage for their deposits, adding support to the thesis that the credibility of the deposit insurance arrangement is critical for its stabilizing role of the banking system.

\section{Final remarks}

Deposit insurance is a widely recognized effective mechanism to mitigate the risk of deposit bank runs. However, this effectiveness is likely closely dependent on the credibility of deposit insurance arrangements. In this paper, we investigate this hypothesis by exploring two events during the Portuguese sovereign debt crisis. The first event is the decision by some foreign banks operating in Portugal to convert their subsidiaries into branches and in the process offer the insurance protection of their home countries instead of that granted by the Portuguese insurance arrangement. Importantly, the converted branches belong to banks from countries with the highest credit ratings. The second event was the announcement in connection with the bailout granted to Cyprus that insured depositors would face losses on their savings.

Our results show that when foreign banks convert their subsidiaries there is a significant deposit inflow into the newly formed branches, even though these banks offer substantially lower interest rates. We also find that depositors in Portugal reacted to the Cyprus announcement, even though there was no direct link between the two countries. Subsequent to the announcement, depositors show a preference for foreign branches operating in Portugal, in particular those belong to banks from countries with the highest credit ratings. On both occasions households, rather than corporations, react the most to the events.

These findings suggest that the credibility of the deposit insurance arrangement is important for the protection it offers banks from depositor runs. The fact 
that on both occasions households react the most to the events adds important support to this assertion. In contrast to corporate deposits, virtually all of the household deposits in Portugal fall under the limit covered by deposit insurance (the median deposits for the highest decile of wealth are 24,700 euros) and thus are exposed to any changes in the protection afforded by the deposit insurance arrangement. Though there is evidence that the existence of deposit insurance mitigates depositors' monitoring incentives, our results suggest that in periods of heightened uncertainty about the insurance mechanism, depositors actively readjust their investments, moving their deposits towards banks that offer them higher protection.

Our findings have several relevant policy implications. For once, they confirm the importance of not altering the rules governing deposit insurance arrangements in ways that inject uncertainty in the protection granted by these arrangements, particularly during financial crises. Further, to the extent that insurance funds account for only a small fraction of eligible deposits, our findings show the importance of government support for the effectiveness of deposit insurance arrangements. In countries or instances where this support is weakened, for example by virtue of high levels of sovereign debt, the stabilization role of deposit insurance arrangements will be compromised. Lastly, at the EU level, our findings show that notwithstanding the harmonization in deposit insurance rules implemented, without a complete Banking Union and a common fiscal backstop, deposit insurance combined with sovereign indebtedness makes 'some euros more equal than others' with implications both for the stability and competitiveness of EU members' banking systems. 


\section{References}

Alanis, E., H. Beladi, and M. Quijano (2015), Uninsured deposits as a monitoring device: Their impact on bond yields of banks, Journal of Banking and Finance, 52, 77-88.

Anginer, D., A. Demirguc-Kunt, and M. Zhu (2014), How does deposit insurance affect bank risk? Evidence from the recent crisis, Journal of Banking \& Finance, 48, 312-321.

Bennett, R., V. Hwa, and M. Kwast (2015), Market discipline by bank creditors during the 2008-2010 crisis, Journal of Financial Stability, 20, 51-69.

Beck, T., S. da Rocha-Lopes, and A. Silva (2020), Sharing the Pain? Credit Supply and Real Effects of Bank Bail-ins, Review of Financial Studies, forthcoming.

Berger, A. and R. Turk-Ariss (2015), Do Depositors Discipline Banks and Did Government Actions During the Recent Crisis Reduce this Discipline? An International Perspective, Journal of Financial Services Research, 48(2), 103-126.

Boyle, G., R. Stover, A. Tiwana, O. Zhylyevskyy (2015), The impact of deposit insurance on depositor behavior during a crisis: A conjoint analysis approach, Journal of Financial Intermediation, 24, 590-601.

Brown, M., I. S. Evangelou and H. Stix (2016), Banking Crises, Bail-ins, and Depositor Confidence: Lessons from Cyprus, mimeo.

Brunnermeier, M. K., L. Garicano, P. R. Lane, M. Pagano, R. Reis, T. Santos, D. Thesmar, S. Van Nieuwerburgh, and D. Vayanos (2016), The Sovereign-Bank Diabolic Loop and ESBies, American Economic Review, 106(5), 508-12.

Bryant, J. (1980), A model of reserves, bank runs, and deposit insurance, Journal of Banking \& Finance, 4(4), 335-344.

Calzolari, G., J. E. Colliard, and G. Lóránth (2019), Multinational Banks and Supranational Supervision, Review of Financial Studies, 32(8), 2997-3035.

Dell'Ariccia, G. and R. Marquez (2010), Risk and the Corporate Structure of Banks, Journal of Finance, 65, 1075-1096.

Demirgüç-Kunt, A. and E. Detagriache (2002), Does deposit insurance increase banking system stability? An empirical investigation, Journal of Monetary Economics, 49, 1373-1406.

Demirgüç-Kunt, A., E. Kane and L. Laeven (2015), Deposit insurance around the world: A comprehensive analysis and database, Journal of Financial Stability, 20, 155-183.

Demirguc-Kunt, A. and H. Huizinga (2013), Are banks too big to fail or too big to save? International evidence from equity prices and CDS spreads, Journal of Banking and Finance, 37(3), 875-894.

Demirgüç-Kunt, A. and H. Huizinga (2004), Market discipline and deposit insurance, Journal of Monetary Economics, 51, 375-399.

Diamond, D. and F. Dybvig (1983), Bank Runs, Deposit Insurance, and Liquidity, Journal of Political Economy, 91(3), 401-419.

Diamond, D. and F. Dybvig (1986), Banking Theory, Deposit Insurance, and Bank Regulation, Journal of Business, 59(1), 55-68. 
Egan, M., A. Hortaçsu, and G. Matvos (2017), Deposit Competition and Financial Fragility: Evidence from the US Banking Sector, American Economic Review, 107 (1), 169-216.

Farhi, E. and J. Tirole (2016), Deadly Embrace: Sovereign and Financial Balance Sheets Doom Loops, NBER Working Paper No. 21843.

Fecht, F., S. Thum, and P. Weber (2019), Fear, deposit insurance schemes, and deposit reallocation in the German banking system, Journal of Banking and Finance, 105, 151-165.

Goldsmith-Pinkham, P. and T. J. Yorulmazer (2010), Liquidity, Bank Runs, and Bailouts: Spillover Effects During the Northern Rock Episode, Journal of Financial Services Research, 37(2), 83-98.

Horvath, B. and H. Huizinga (2015), Does the European financial stability bail out sovereigns or banks: An event study, Journal of Money, Credit and Banking, 47(1), 177-206.

loannidou, V. and M. F. Penas (2010), Deposit Insurance and Bank Risk-taking: Evidence from Internal Loan Ratings, Journal of Financial Intermediation, 19(1), 95-115.

lyer, R. and M. Puri (2012), Understanding Bank Runs: The Importance of Depositor-Bank Relationships and Networks, American Economic Review, 102(4), 1414-1445.

lyer, R., M. Puri, and N. Ryan (2016), A tale of two runs: Depositor responses to bank solvency risk, Journal of Finance, 71(6), 2687-2726.

Karas, A., W. Pyle, and K. Schoors (2013), Deposit insurance, banking crises, and market discipline: Evidence from a natural experiment on deposit flows and rates, Journal of Money, Credit and Banking, 45(1), 179-200.

Lamers, M. (2015), Depositor discipline and bank failures in local markets during the financial crisis, mimeo.

Leonello, A. (2018), Government Guarantees and the Two-Way Feedback between Banking and Sovereign Debt Crises, Journal of Financial Economics, 130(3), 592-619,

Martinez Peria, M. S. and S. Schmukler (2001), Do depositors punish banks for bad behavior? Market discipline, deposit insurance, and banking crises, Journal of Finance, 56(3), 1029-1051.

Shin, H. S. (2009), Reflections on Northern Rock: The Bank Run that Heralded the Global Financial Crisis, Journal of Economic Perspectives, 23(1), 101-119. 


\section{Tables and Figures}

\begin{tabular}{|c|c|c|c|c|c|c|}
\hline & $\mathbf{N}$ & mean & p5 & median & p95 & \\
\hline Total deposits (log) & 3090 & 5.97 & 2.83 & 5.59 & 9.95 & \\
\hline Households deposits (log) & 3132 & 5.27 & 0.69 & 5.36 & 9.59 & \\
\hline Corporate deposits $(\log )$ & 3663 & 4.24 & 0.69 & 3.69 & 8.21 & \\
\hline Total deposits (monthly growth rate) & 3019 & 0.74 & -11.71 & 0.00 & 14.58 & \\
\hline Households deposits (monthly growth rate) & 3063 & 0.57 & -7.14 & 0.00 & 9.38 & \\
\hline Corporate deposits (monthly growth rate) & 3603 & 3.02 & -27.27 & 0.00 & 34.98 & \\
\hline Non-performing loans & 4276 & 7.34 & 0.00 & 3.31 & 25.34 & \\
\hline Leverage & 4273 & 7.34 & -2.83 & 5.67 & 26.21 & \\
\hline Loan to deposit ratio & 3947 & 334.7 & 10.61 & 149.8 & 1000 & \\
\hline ROA & 4257 & 0.55 & -2.99 & 0.37 & 4.32 & \\
\hline Net interest margin & 4272 & 2.97 & 0.15 & 1.49 & 10.64 & \\
\hline Liquidity ratio & 4245 & 216.4 & 0.70 & 53.63 & 1000 & \\
\hline Total capital ratio & 3065 & 15.45 & 7.99 & 12.30 & 39.99 & \\
\hline Log of total assets & 4276 & 21.09 & 17.97 & 20.89 & 24.92 & \\
\hline Interest rate on household deposits & 1662 & 2.85 & 0.94 & 2.78 & 4.86 & \\
\hline Interest rate on corporate deposits & 1934 & 2.46 & 0.30 & 2.27 & 4.93 & \\
\hline Dummy domestic banks & 4276 & 0.54 & 0.00 & 1.00 & 1.00 & \\
\hline Dummy foreign branches & 4276 & 0.27 & 0.00 & 0.00 & 1.00 & \\
\hline Dummy foreign subsidiaries & 4276 & 0.19 & 0.00 & 0.00 & 1.00 & \\
\hline \multirow[t]{3}{*}{ Panel B - by bank type } & \multirow{2}{*}{\multicolumn{2}{|c|}{ Domestic banks }} & \multirow{2}{*}{\multicolumn{2}{|c|}{ Foreign branches }} & \multirow{2}{*}{\multicolumn{2}{|c|}{ Foreign subsidiaries }} \\
\hline & & & & & & \\
\hline & $\mathbf{N}$ & mean & $\mathbf{N}$ & mean & $\mathbf{N}$ & mean \\
\hline Total deposits (log) & 2035 & 6.26 & 647 & 4.61 & 408 & 6.62 \\
\hline Households deposits (log) & 2047 & 5.81 & 677 & 3.27 & 408 & 5.83 \\
\hline Corporate deposits (log) & 2154 & 4.42 & 939 & 3.42 & 570 & 4.89 \\
\hline Total deposits (monthly growth rate) & 2002 & 0.58 & 620 & 1.01 & 397 & 1.13 \\
\hline Households deposits (monthly growth rate) & 2014 & 0.65 & 652 & 0.17 & 397 & 0.87 \\
\hline Corporate deposits (monthly growth rate) & 2121 & 1.80 & 925 & 5.99 & 557 & 2.74 \\
\hline Non-performing loans & 2297 & 9.60 & 1165 & 4.41 & 814 & 5.20 \\
\hline Leverage & 2297 & 8.84 & 1162 & 3.34 & 814 & 8.81 \\
\hline Loan to deposit ratio & 2265 & 240.9 & 975 & 484.2 & 707 & 428.7 \\
\hline ROA & 2286 & 0.56 & 1160 & 0.27 & 811 & 0.92 \\
\hline Net interest margin & 2296 & 2.83 & 1162 & 2.63 & 814 & 3.87 \\
\hline Liquidity ratio & 2268 & 309.9 & 1163 & 108.7 & 814 & 109.7 \\
\hline Total capital ratio & 2264 & 15.64 & - & - & 800 & 14.84 \\
\hline Log of total assets & 2297 & 21.32 & 1165 & 20.18 & 814 & 21.76 \\
\hline Interest rate on household deposits & 1184 & 3.13 & 266 & 2.00 & 212 & 2.40 \\
\hline Interest rate on corporate deposits & 1226 & 2.88 & 475 & 1.46 & 233 & 2.32 \\
\hline Dummy domestic banks & 2297 & 1.00 & 1165 & 0.00 & 814 & 0.00 \\
\hline Dummy foreign branches & 2297 & 0.00 & 1165 & 1.00 & 814 & 0.00 \\
\hline Dummy foreign subsidiaries & 2297 & 0.00 & 1165 & 0.00 & 814 & 1.00 \\
\hline
\end{tabular}

Table 1. Summary statistics

Notes: The sample covers monthly bank level data between March 2007 and December 2013 Corporate deposits refer to deposits from non-financial corporations. Non-performing loans reported as a percentage of total credit. Leverage is defined as equity as a percentage of total assets. ROA computed as net profits as a \% of total assets and net interest margin computed as \% of total assets. The liquidity ratio is defined as liquid assets as a percentage of interbank liabilities. The total capital ratio is the regulatory capital ratio and is not available for branches from EU countries. The loan to deposit and the liquidity ratio are truncated at 1000 . 


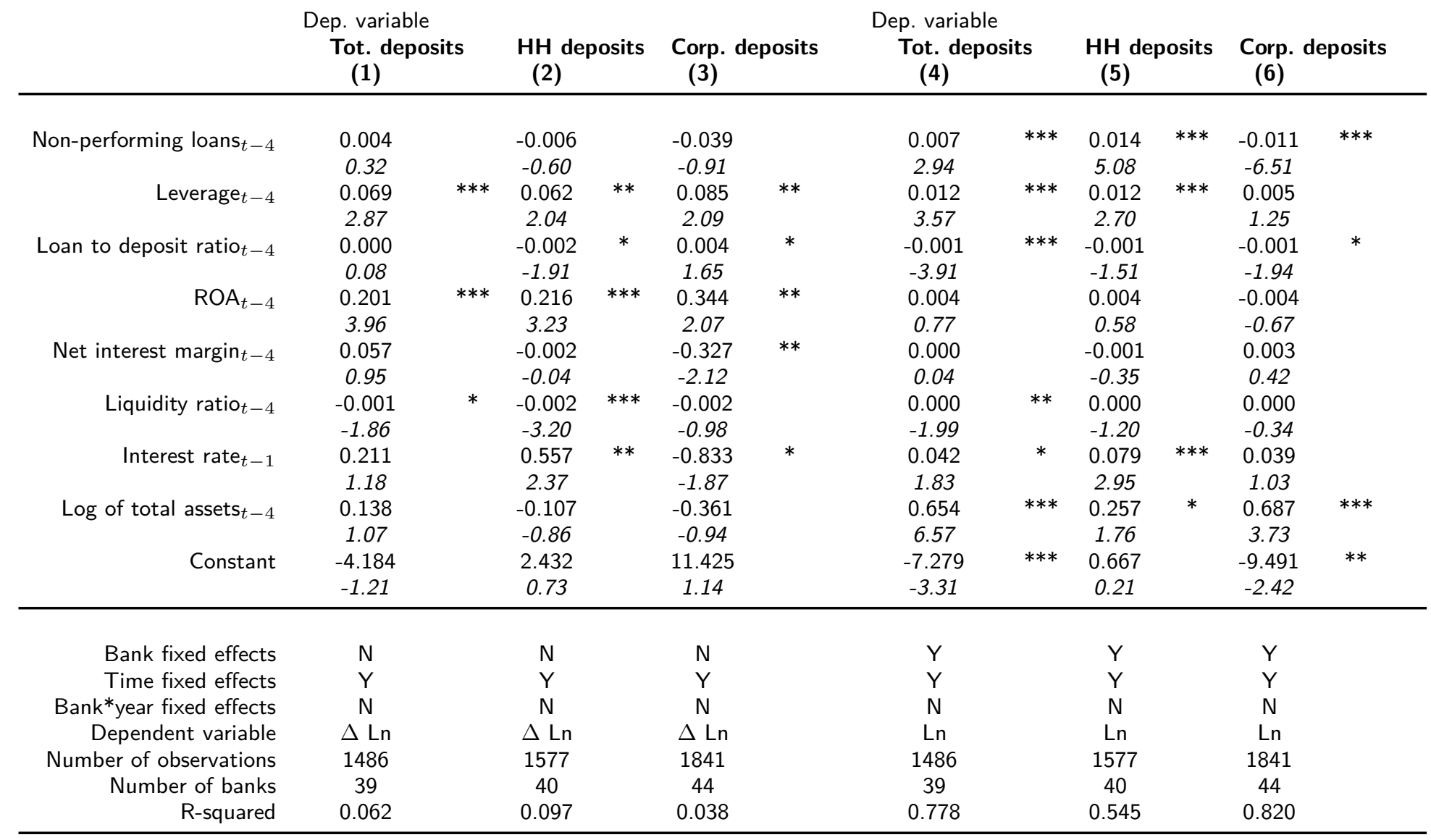

Table 2. Determinants of deposits

Notes: T-stats reported in italics and standard errors clustered by bank. Explanatory variables lagged by one year, except for interest rates (lagged by one quarter). Corporate deposits refer to deposits from non-financial corporations. Leverage is defined as equity as a percentage of total assets. ROA computed as net profits as a \% of total assets and net interest margin computed as \% of total assets. The liquidity ratio is defined as liquid assets as a percentage of interbank liabilities. The total capital ratio is the regulatory capital ratio and is not available for branches from EU countries. ${ }^{* * *}$ significant at $1 \%,{ }^{* *}$ significant at $5 \%$, *significant at $10 \%$. 


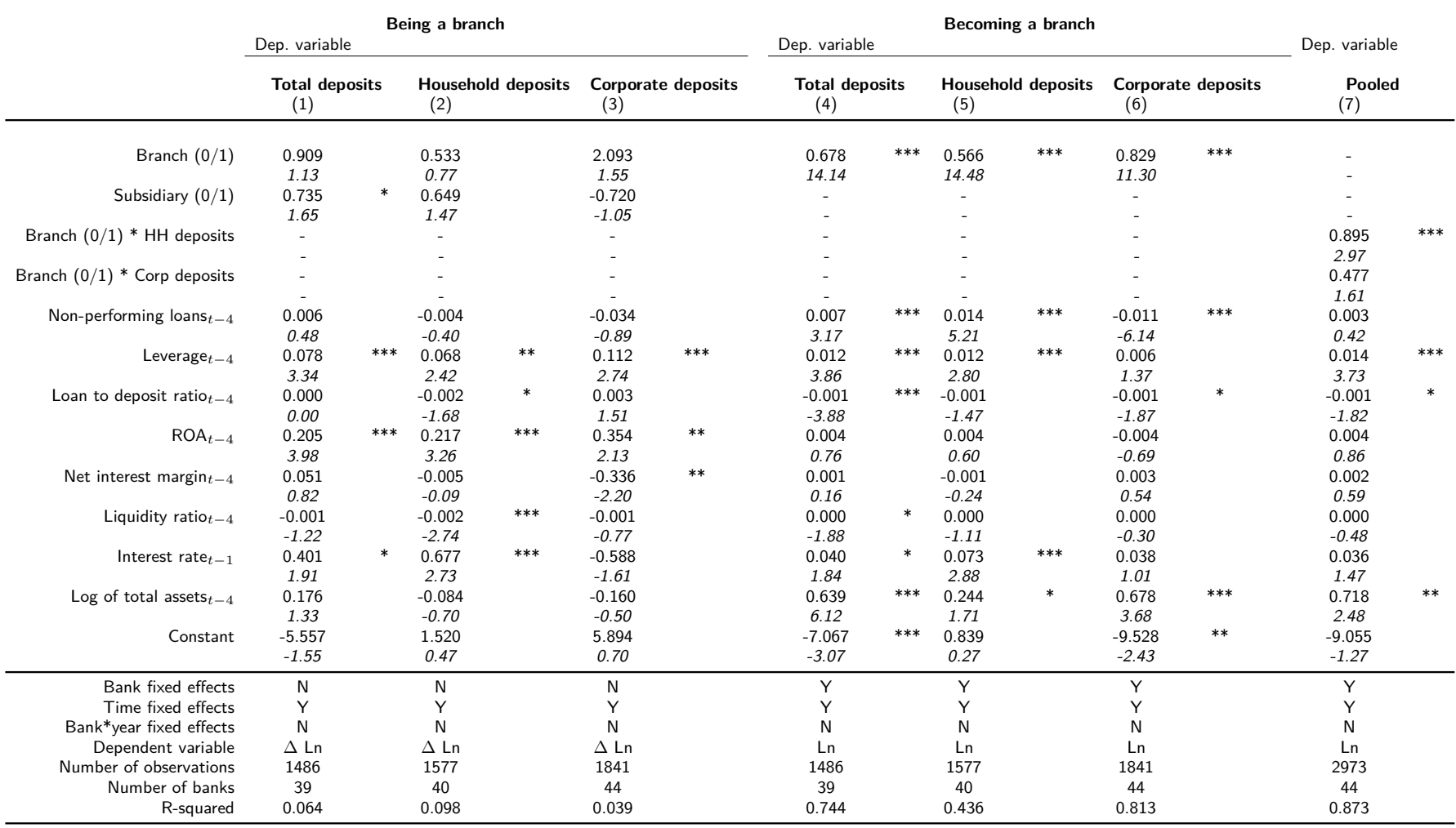

Table 3. The effect of being or becoming a branch on deposits

Notes: T-stats reported in italics and standard errors clustered by bank. Explanatory variables lagged by one year, except for interest rates (lagged by one quarter). The first three columns examine the effects of being a branch (or subsidiary) on deposit growth. The last three columns examine the effects of becoming a branch on the level of deposits, using bank fixed effects. Corporate deposits refer to deposits from non-financial corporations. Leverage is defined as equity as a percentage of total assets. ROA computed as net profits as a $\%$ of total assets and net interest margin computed as $\%$ of total assets. The liquidity ratio is defined as liquid assets as a percentage of interbank liabilities. The total capital ratio is the regulatory capital ratio and is not available for branches from EU countries. $* * *$ significant at $1 \%,{ }^{* *}$ significant at $5 \%$, *significant at $10 \%$. 


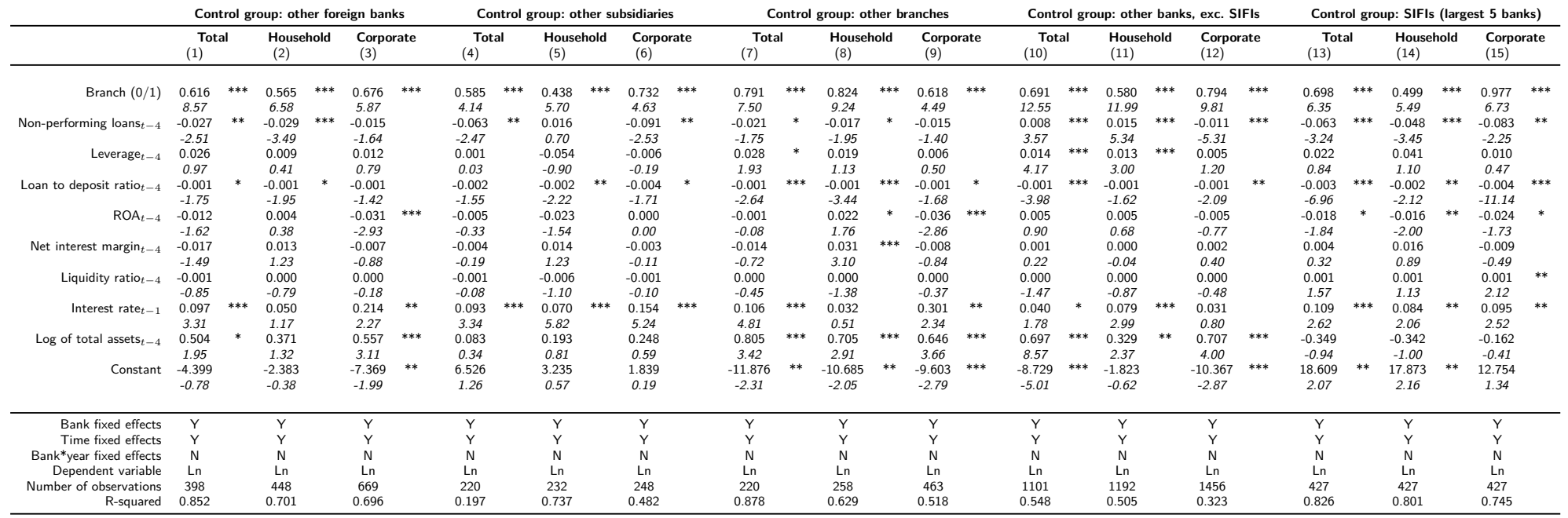

Table 4. Exploring the transformation of foreign subsidiaries in branches - other control groups

Notes: T-stats reported in italics and standard errors clustered by bank. Explanatory variables lagged by one year, except for interest rates (lagged by one quarter). Corporate deposits refer to deposits from non-financial corporations. Leverage is defined as equity as a percentage of total assets. ROA computed as net profits as a \% of total assets and net interest margin computed as \% of total assets. The liquidity ratio is defined as liquid assets as a percentage of interbank liabilities. The total capital ratio is the regulatory capital ratio and is not available for branches from EU countries. *** significant at $1 \%$, ** significant at $5 \%$, *significant at $10 \%$. 
Bank*year fixed effects

Differences in differences

\begin{tabular}{|c|c|c|c|c|c|c|c|c|c|c|c|c|}
\hline \multirow[b]{2}{*}{ Aftert * Branch } & \multicolumn{2}{|c|}{$\begin{array}{l}\text { Total } \\
(1)\end{array}$} & \multicolumn{2}{|c|}{$\begin{array}{l}\text { Household } \\
\text { (2) }\end{array}$} & \multicolumn{2}{|c|}{$\begin{array}{l}\text { Corporate } \\
\text { (3) }\end{array}$} & \multicolumn{2}{|c|}{$\begin{array}{l}\text { Total } \\
(4)^{-}\end{array}$} & \multicolumn{2}{|c|}{$\begin{array}{l}\text { Household } \\
\text { (5) }\end{array}$} & \multicolumn{2}{|c|}{$\begin{array}{l}\text { Corporate } \\
(6)\end{array}$} \\
\hline & & & & & & & $\begin{array}{c}1.487 \\
4.36\end{array}$ & $* * *$ & $\begin{array}{c}1.322 \\
2.68\end{array}$ & $* * *$ & $\begin{array}{c}1.123 \\
2.91\end{array}$ & $* * *$ \\
\hline Branch $(0 / 1)$ & $\begin{array}{c}0.212 \\
3.79\end{array}$ & $* * *$ & $\begin{array}{c}0.336 \\
5.31\end{array}$ & $* * *$ & $\begin{array}{c}0.064 \\
0.44\end{array}$ & & $\begin{array}{l}-1.576 \\
-2.71\end{array}$ & $* * *$ & $\begin{array}{l}-1.528 \\
-1.89\end{array}$ & $*$ & $\begin{array}{c}0.001 \\
0.00\end{array}$ & \\
\hline Subsidiary $(0 / 1)$ & & & & & & & $\begin{array}{l}-0.51 \\
-1.54\end{array}$ & & $\begin{array}{l}-0.98 \\
-1.49\end{array}$ & & $\begin{array}{l}0.24 \\
0.68\end{array}$ & \\
\hline Non-performing loans $t-4$ & $\begin{array}{c}0.004 \\
5.22\end{array}$ & $* * *$ & $\begin{array}{c}0.004 \\
5.15\end{array}$ & $* * *$ & $\begin{array}{c}0.001 \\
0.67\end{array}$ & & $\begin{array}{c}-0.009 \\
-1.69\end{array}$ & $*$ & $\begin{array}{c}-0.005 \\
-0.70\end{array}$ & & $\begin{array}{c}-0.017 \\
-2.27\end{array}$ & $* *$ \\
\hline Leverage $_{t-4}$ & $\begin{array}{c}0.013 \\
7.71\end{array}$ & $* * *$ & $\begin{array}{c}0.013 \\
7.35\end{array}$ & $* * *$ & $\begin{array}{c}0.002 \\
0.66\end{array}$ & & $\begin{array}{c}-0.010 \\
-1.10\end{array}$ & & $\begin{array}{c}-0.008 \\
-0.57\end{array}$ & & $\begin{array}{c}-0.011 \\
-0.89\end{array}$ & \\
\hline Loan to deposit ratio $t-4$ & $\begin{array}{c}-0.001 \\
-7.09\end{array}$ & $* * *$ & $\begin{array}{c}-0.001 \\
-6.51\end{array}$ & $* * *$ & $\begin{array}{l}0.000 \\
-2.19\end{array}$ & $* *$ & $\begin{array}{c}0.001 \\
0.75\end{array}$ & & $\begin{array}{c}0.001 \\
0.40\end{array}$ & & $\begin{array}{l}-0.001 \\
-1.12\end{array}$ & \\
\hline $\mathrm{ROA}_{t-4}$ & $\begin{array}{c}0.000 \\
0.26\end{array}$ & & $\begin{array}{l}-0.002 \\
-1.04\end{array}$ & & $\begin{array}{c}0.004 \\
1.30\end{array}$ & & $\begin{array}{c}0.005 \\
0.27\end{array}$ & & 0.011 & & -0.039 & \\
\hline Net interest margin $_{t-4}$ & $\begin{array}{c}0.000 \\
0.24\end{array}$ & & $\begin{array}{c}0.001 \\
0.72\end{array}$ & & $\begin{array}{l}-0.001 \\
-0.67\end{array}$ & & $\begin{array}{c}0.095 \\
2.38\end{array}$ & $* *$ & $\begin{array}{c}0.098 \\
1.78\end{array}$ & $*$ & $\begin{array}{c}0.050 \\
1.58\end{array}$ & \\
\hline Liquidity ratio $t-4$ & $\begin{array}{c}0.000 \\
0.25\end{array}$ & & $\begin{array}{l}0.000 \\
-1.13\end{array}$ & & $\begin{array}{l}0.000 \\
-0.50\end{array}$ & & $\begin{array}{c}0.001 \\
2.08\end{array}$ & $* *$ & $\begin{array}{c}0.001 \\
2.24\end{array}$ & $* *$ & $\begin{array}{l}0.000 \\
-0.60\end{array}$ & \\
\hline Interest rate $t-1$ & $\begin{array}{c}0.020 \\
3.91\end{array}$ & $* * *$ & $\begin{array}{c}0.024 \\
4.49\end{array}$ & $* * *$ & $\begin{array}{c}0.014 \\
1.57\end{array}$ & & $\begin{array}{l}-0.180 \\
-0.94\end{array}$ & & $\begin{array}{c}-0.279 \\
-1.14\end{array}$ & & $\begin{array}{c}-0.022 \\
-0.24\end{array}$ & \\
\hline Log of total assets $t_{t-4}$ & $\begin{array}{l}0.599 \\
15.11\end{array}$ & $* * *$ & $\begin{array}{c}0.353 \\
8.36\end{array}$ & $* * *$ & $\begin{array}{c}0.373 \\
5.51\end{array}$ & $* * *$ & $\begin{array}{l}1.067 \\
13.82\end{array}$ & $* * *$ & $\begin{array}{c}1.130 \\
9.68\end{array}$ & $* * *$ & $\begin{array}{l}0.954 \\
13.51\end{array}$ & $* * *$ \\
\hline Bank fixed effects & $\mathrm{N}$ & & $\mathrm{N}$ & & $\mathrm{N}$ & & $\mathrm{N}$ & & $\mathrm{N}$ & & $\mathrm{N}$ & \\
\hline Time fixed effects & $\mathrm{N}$ & & $\mathrm{N}$ & & $\mathrm{N}$ & & $\mathrm{Y}$ & & $\mathrm{Y}$ & & $\mathrm{Y}$ & \\
\hline Bank*year fixed effects & $\mathrm{Y}$ & & $\mathrm{Y}$ & & $\mathrm{Y}$ & & $\mathrm{N}$ & & $\mathrm{N}$ & & $\mathrm{N}$ & \\
\hline Dependent variable & $\operatorname{Ln}$ & & $\mathrm{Ln}$ & & $\mathrm{Ln}$ & & $\operatorname{Ln}$ & & $\operatorname{Ln}$ & & $\mathrm{Ln}$ & \\
\hline Number of observations & 1478 & & 1573 & & 1838 & & 1486 & & 1577 & & 1841 & \\
\hline Number of banks & 39 & & 40 & & 44 & & 39 & & 40 & & 44 & \\
\hline R-squared & 0.999 & & 0.999 & & 0.990 & & 0.888 & & 0.813 & & 0.854 & \\
\hline
\end{tabular}

Table 5. Exploring the transformation of foreign subsidiaries in branches - other approaches

Notes: T-stats reported in italics and standard errors clustered by bank. Explanatory variables lagged by one year, except for interest rates (lagged by one quarter). After is equal to 1 after subsidiaries are converted to branches Corporate deposits refer to deposits from non-financial corporations. Leverage is defined as equity as a percentage of total assets. ROA computed as net profits as a \% of total assets and net interest margin computed as $\%$ of total assets. The liquidity ratio is defined as liquid assets as a percentage of interbank liabilities. The total capital ratio is the regulatory capital ratio and is not available for branches from EU countries. ${ }^{* * *}$ significant at $1 \%,{ }^{* *}$ significant at $5 \%, *$ significant at $10 \%$. 


\begin{tabular}{|c|c|c|c|c|c|c|c|c|c|c|c|c|}
\hline \multirow[b]{2}{*}{ Cyprus } & \multicolumn{2}{|l|}{$\begin{array}{c}\text { Total } \\
(1)\end{array}$} & \multicolumn{2}{|c|}{$\begin{array}{l}\text { Household } \\
\text { (2) }\end{array}$} & \multicolumn{2}{|c|}{$\begin{array}{c}\text { Corporate } \\
\text { (3) }\end{array}$} & \multicolumn{2}{|l|}{$\begin{array}{c}\text { Total } \\
(4)\end{array}$} & \multicolumn{2}{|c|}{$\begin{array}{l}\text { Household } \\
\text { (5) }\end{array}$} & \multicolumn{2}{|c|}{$\begin{array}{l}\text { Corporate } \\
\text { (6) }\end{array}$} \\
\hline & $\begin{array}{c}0.937 \\
1.40\end{array}$ & & $\begin{array}{l}-0.907 \\
-1.72\end{array}$ & * & $\begin{array}{c}2.740 \\
0.41\end{array}$ & & $\begin{array}{c}0.020 \\
0.55\end{array}$ & & $\begin{array}{c}0.045 \\
1.07\end{array}$ & & $\begin{array}{l}-0.044 \\
-0.71\end{array}$ & \\
\hline Dummy subsidiary & 0.909 & & 0.533 & & 2.093 & & 0.678 & $* * *$ & 0.566 & $* * *$ & 0.829 & *** \\
\hline & 1.13 & & 0.77 & & 1.55 & & 14.14 & & 14.48 & & 11.30 & \\
\hline Dummy branch & $\begin{array}{c}0.735 \\
1.65\end{array}$ & * & $\begin{array}{c}0.649 \\
1.47\end{array}$ & & $\begin{array}{l}-0.720 \\
-1.05\end{array}$ & & $\begin{array}{c}0.000 \\
0.00\end{array}$ & & $\begin{array}{c}0.000 \\
0.00\end{array}$ & & $\begin{array}{c}0.000 \\
0.00\end{array}$ & \\
\hline Non-performing loans & $\begin{array}{l}0.006 \\
0.48\end{array}$ & & $\begin{array}{l}-0.004 \\
-0.40\end{array}$ & & $\begin{array}{l}-0.034 \\
-0.89\end{array}$ & & $\begin{array}{l}0.007 \\
3.17\end{array}$ & $* * *$ & $\begin{array}{c}0.014 \\
5.21\end{array}$ & $* * *$ & $\begin{array}{l}-0.011 \\
-6.14\end{array}$ & *** \\
\hline Leverage & $\begin{array}{c}0.078 \\
3.34\end{array}$ & $* * *$ & $\begin{array}{c}0.068 \\
2.42\end{array}$ & $* *$ & $\begin{array}{c}0.112 \\
2.74\end{array}$ & $* * *$ & $\begin{array}{l}0.012 \\
3.86\end{array}$ & $* * *$ & $\begin{array}{c}0.012 \\
2.80\end{array}$ & $* * *$ & $\begin{array}{c}0.006 \\
1.37\end{array}$ & \\
\hline Loan to deposit ratio & $\begin{array}{c}0.000 \\
0.00\end{array}$ & & $\begin{array}{l}-0.002 \\
-1.68\end{array}$ & $*$ & $\begin{array}{c}0.003 \\
1.51\end{array}$ & & $\begin{array}{l}-0.001 \\
-3.88\end{array}$ & $* * *$ & $\begin{array}{l}-0.001 \\
-1.47\end{array}$ & & $\begin{array}{l}-0.001 \\
-1.87\end{array}$ & * \\
\hline ROA & $\begin{array}{c}0.205 \\
3.98\end{array}$ & $* * *$ & $\begin{array}{c}0.217 \\
3.26\end{array}$ & $* * *$ & $\begin{array}{l}0.354 \\
2.13\end{array}$ & $* *$ & $\begin{array}{c}0.004 \\
0.76\end{array}$ & & $\begin{array}{c}0.004 \\
0.60\end{array}$ & & $\begin{array}{l}-0.004 \\
-0.69\end{array}$ & \\
\hline Net interest margin & $\begin{array}{c}0.051 \\
0.82\end{array}$ & & $\begin{array}{l}-0.005 \\
-0.09\end{array}$ & & $\begin{array}{l}-0.336 \\
-2.20\end{array}$ & $* *$ & $\begin{array}{c}0.001 \\
0.16\end{array}$ & & $\begin{array}{l}-0.001 \\
-0.24\end{array}$ & & $\begin{array}{c}0.003 \\
0.54\end{array}$ & \\
\hline Liquidity ratio & $\begin{array}{l}-0.001 \\
-1.22\end{array}$ & & $\begin{array}{l}-0.002 \\
-2.74\end{array}$ & $* * *$ & $\begin{array}{l}-0.001 \\
-0.77\end{array}$ & & $\begin{array}{l}0.000 \\
-1.88\end{array}$ & * & $\begin{array}{l}0.000 \\
-1.11\end{array}$ & & $\begin{array}{l}0.000 \\
-0.30\end{array}$ & \\
\hline Interest rate & 0.401 & * & 0.677 & $* * *$ & -0.588 & & 0.040 & * & 0.073 & $* * *$ & 0.038 & \\
\hline & 1.91 & & 2.73 & & -1.61 & & 1.84 & & 2.88 & & 1.01 & \\
\hline Log of total assets & 0.176 & & -0.084 & & -0.160 & & 0.639 & *** & 0.244 & * & 0.678 & *** \\
\hline & 1.33 & & -0.70 & & -0.50 & & 6.12 & & 1.71 & & 3.68 & \\
\hline Constant & $\begin{array}{l}-5.557 \\
-1.55\end{array}$ & & $\begin{array}{l}1.520 \\
0.47\end{array}$ & & $\begin{array}{l}5.894 \\
0.70\end{array}$ & & $\begin{array}{l}-7.067 \\
-3.07\end{array}$ & $* * *$ & $\begin{array}{c}0.839 \\
0.27\end{array}$ & & $\begin{array}{l}-9.528 \\
-2.43\end{array}$ & $* *$ \\
\hline Bank fixed effects & $\mathrm{N}$ & & $\mathrm{N}$ & & $\mathrm{N}$ & & $\mathrm{Y}$ & & $\mathrm{Y}$ & & $\mathrm{Y}$ & \\
\hline Time fixed effects & $\mathrm{Y}$ & & $\mathrm{Y}$ & & Y & & $\mathrm{Y}$ & & $\mathrm{Y}$ & & $\mathrm{Y}$ & \\
\hline Bank*year fixed effects & $\mathrm{N}$ & & $\mathrm{N}$ & & $\mathrm{N}$ & & $\mathrm{N}$ & & $\mathrm{N}$ & & $\mathrm{N}$ & \\
\hline Dependent variable & $\Delta \operatorname{Ln}$ & & $\Delta \operatorname{Ln}$ & & $\Delta \operatorname{Ln}$ & & Ln & & $\operatorname{Ln}$ & & $\operatorname{Ln}$ & \\
\hline Period & Full samp & & Full samp & & Full samp & & Full samp & & Full samp & & Full samp & \\
\hline Bank controls & $\mathrm{Y}$ & & $\mathrm{Y}$ & & $\mathrm{Y}$ & & $\mathrm{Y}$ & & $\mathrm{Y}$ & & $\mathrm{Y}$ & \\
\hline Number of observations & 1486 & & 1577 & & 1841 & & 671 & & 705 & & 808 & \\
\hline Number of banks & 39 & & 40 & & 44 & & 33 & & 33 & & 39 & \\
\hline R-squared & 0.064 & & 0.098 & & 0.039 & & 0.744 & & 0.436 & & 0.813 & \\
\hline
\end{tabular}

Table 6. The effects on uncertainty on deposit insurance associated with the Cyprus event

Notes: T-stats reported in italics and standard errors clustered by bank. Explanatory variables lagged by one quarter. The Cyprus dummy takes the value one in March and April 2013. Corporate deposits refer to deposits from non-financial corporations. Leverage is defined as equity as a percentage of total assets. ROA computed as net profits as a $\%$ of total assets and net interest margin computed as $\%$ of total assets. The liquidity ratio is defined as liquid assets as a percentage of interbank liabilities. The total capital ratio is the regulatory capital ratio and is not available for branches from EU countries. ${ }^{* * *}$ significant at $1 \%,{ }^{* *}$ significant at $5 \%,{ }^{*}$ significant at $10 \%$. 


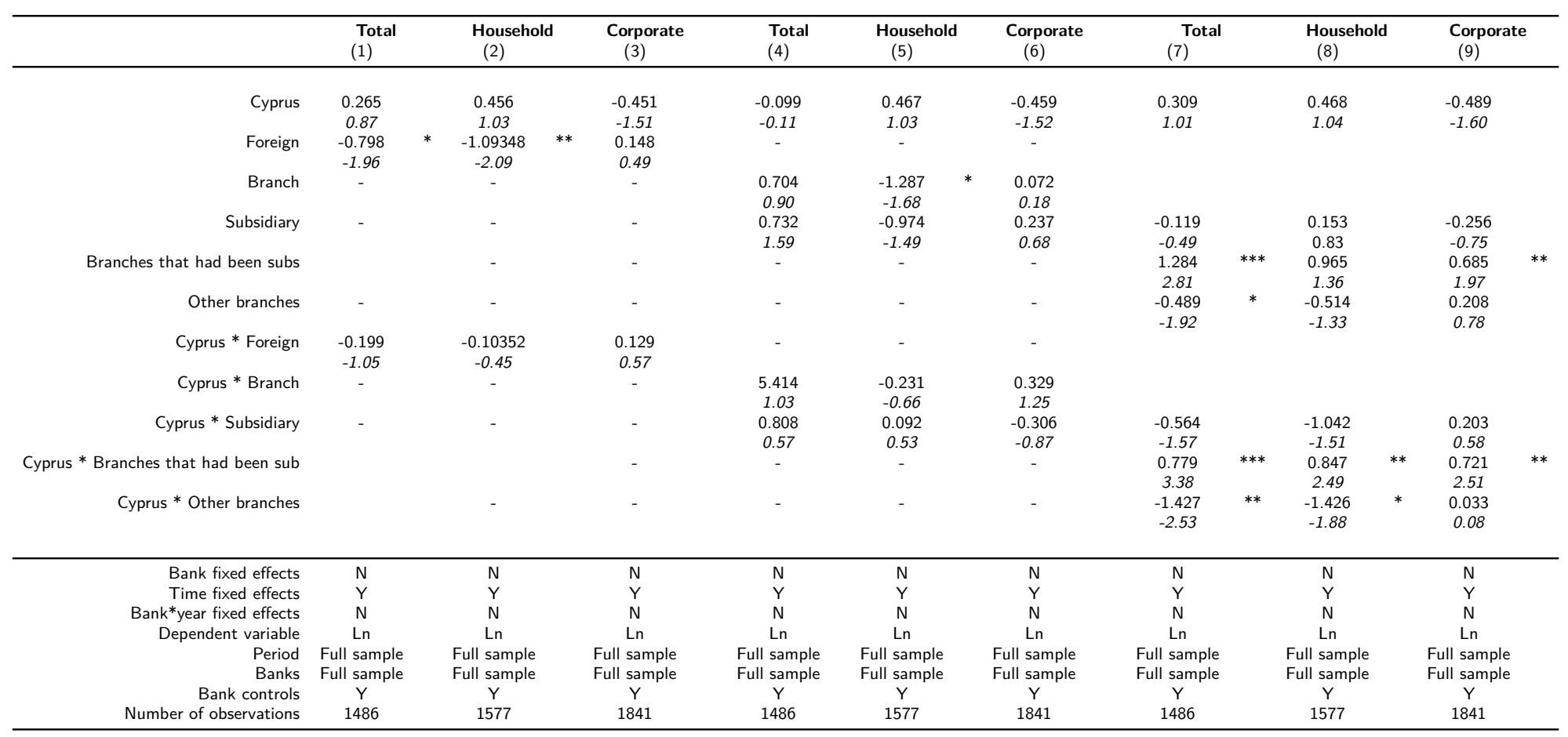

Table 7. The effects on uncertainty on deposit insurance associated with the Cyprus event for foreign banks

Notes: T-stats reported in italics and standard errors clustered by bank. Explanatory variables lagged by one quarter. The regressions in columns 1-6 include all banks, the regressions in columns 7-9 include only foreign banks, the regressions in columns 10-12 include only foreign branches, and the regressions in columns 13-15 include only the subsidiaries that became branches. The Cyprus dummy takes the value one in March and April 2013. Corporate deposits refer to deposits from non-financial corporations. ${ }^{* * *}$ significant at $1 \%,{ }^{* *}$ significant at $5 \%$, ${ }^{*}$ significant at $10 \%$. 


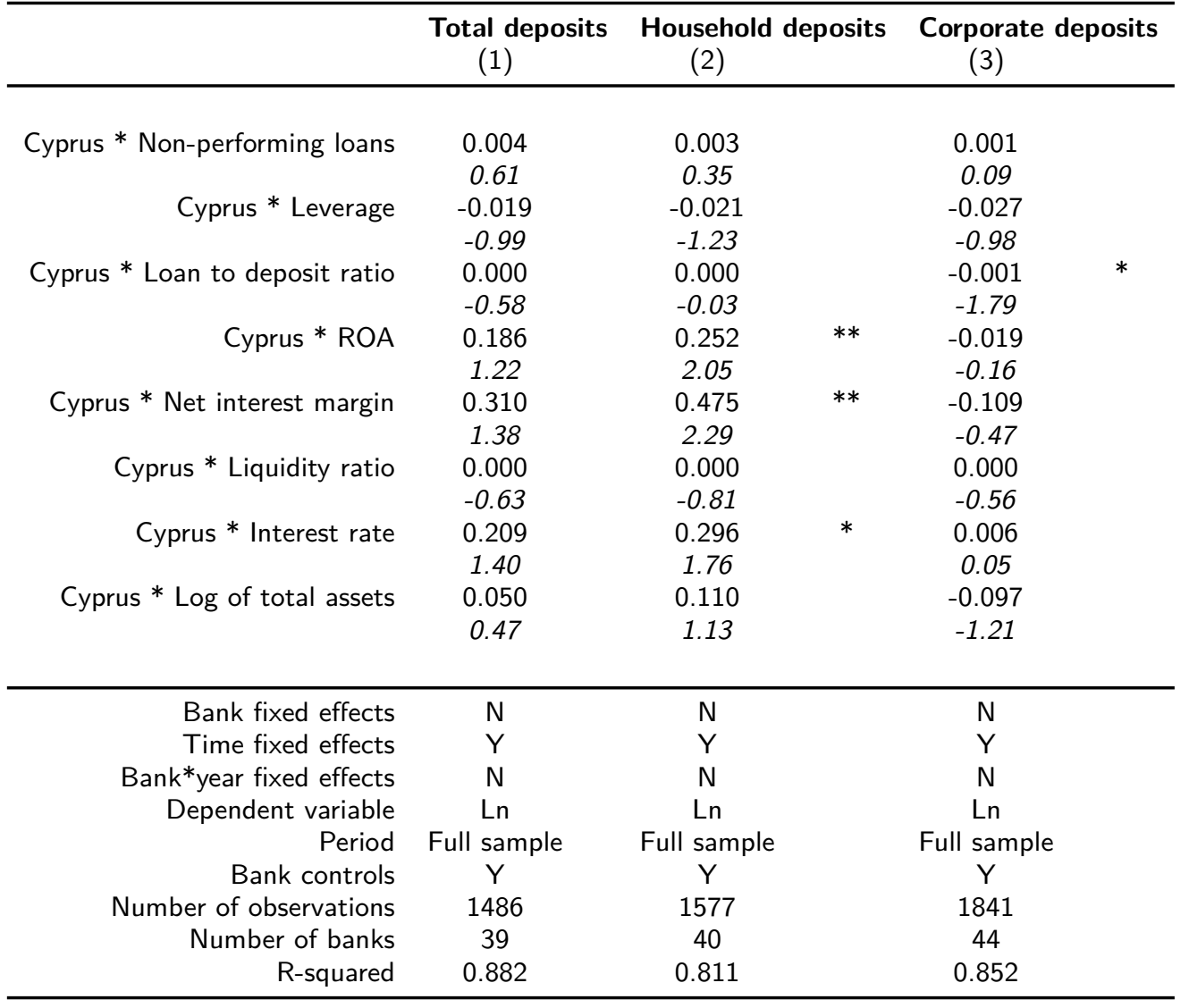

Table 8. The effects on uncertainty on deposit insurance associated with the Cyprus event across banks

Notes: T-stats reported in italics and standard errors clustered by bank. All regressions include month fixed effects. Explanatory variables lagged by one quarter. The Cyprus dummy takes the value one in March and April 2013. Corporate deposits refer to deposits from non-financial corporations. Leverage is defined as equity as a percentage of total assets. ROA computed as net profits as a $\%$ of total assets and net interest margin computed as \% of total assets. The liquidity ratio is defined as liquid assets as a percentage of interbank liabilities. The total capital ratio is the regulatory capital ratio and is not available for branches from EU countries. $* * *$ significant at $1 \%$, ** significant at $5 \%$, *significant at $10 \%$. 


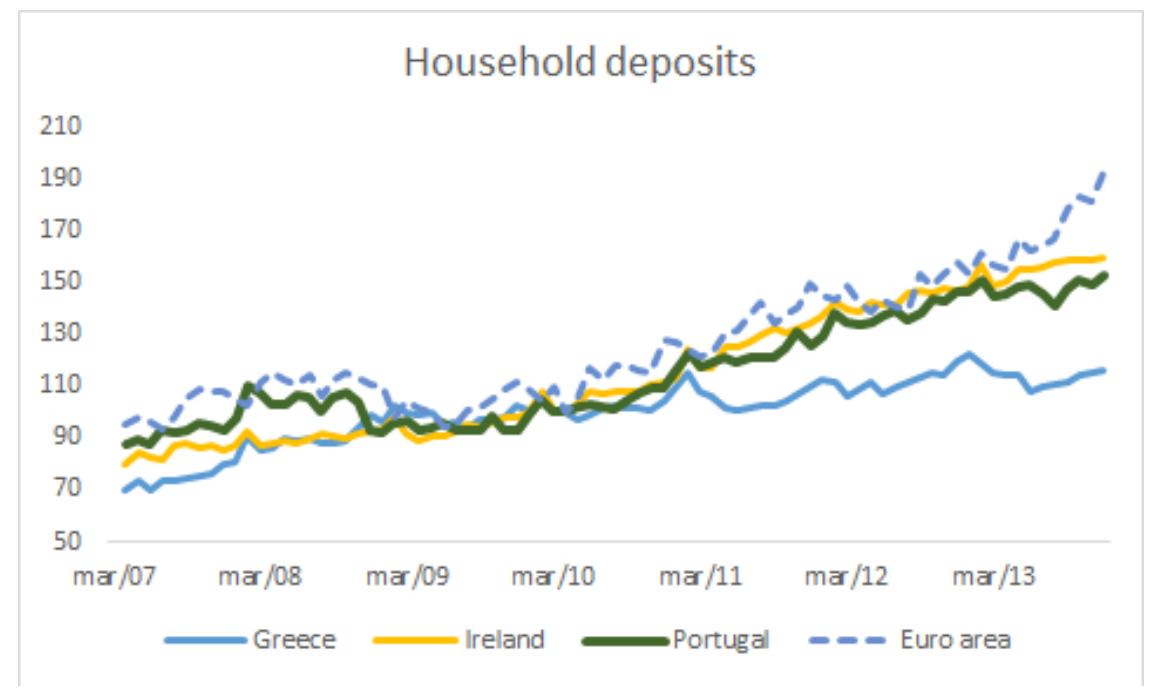

Figure 1: The evolution of household deposits in Europe 

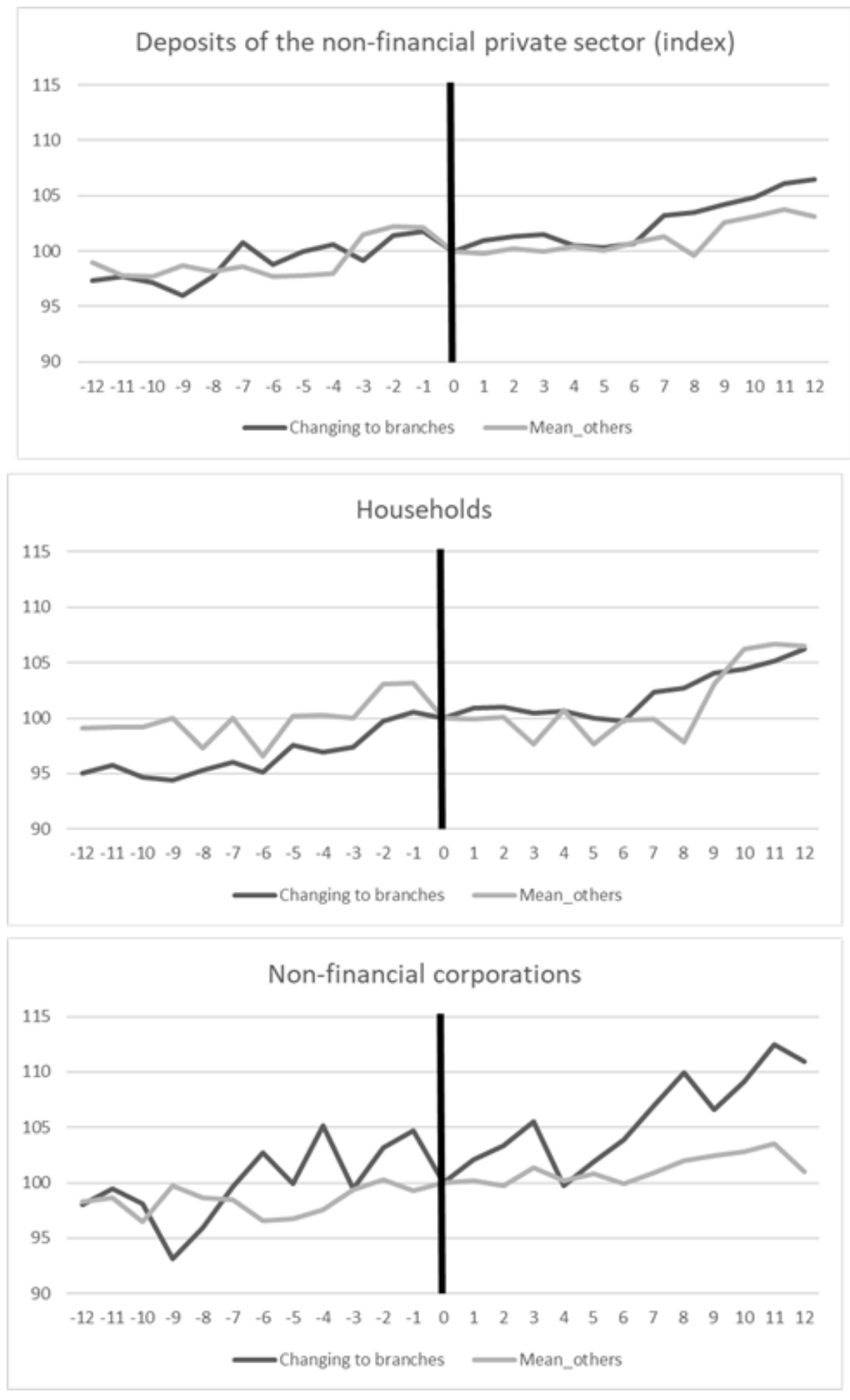

Figure 2: Evolution of bank deposits - effects from changing to branches 

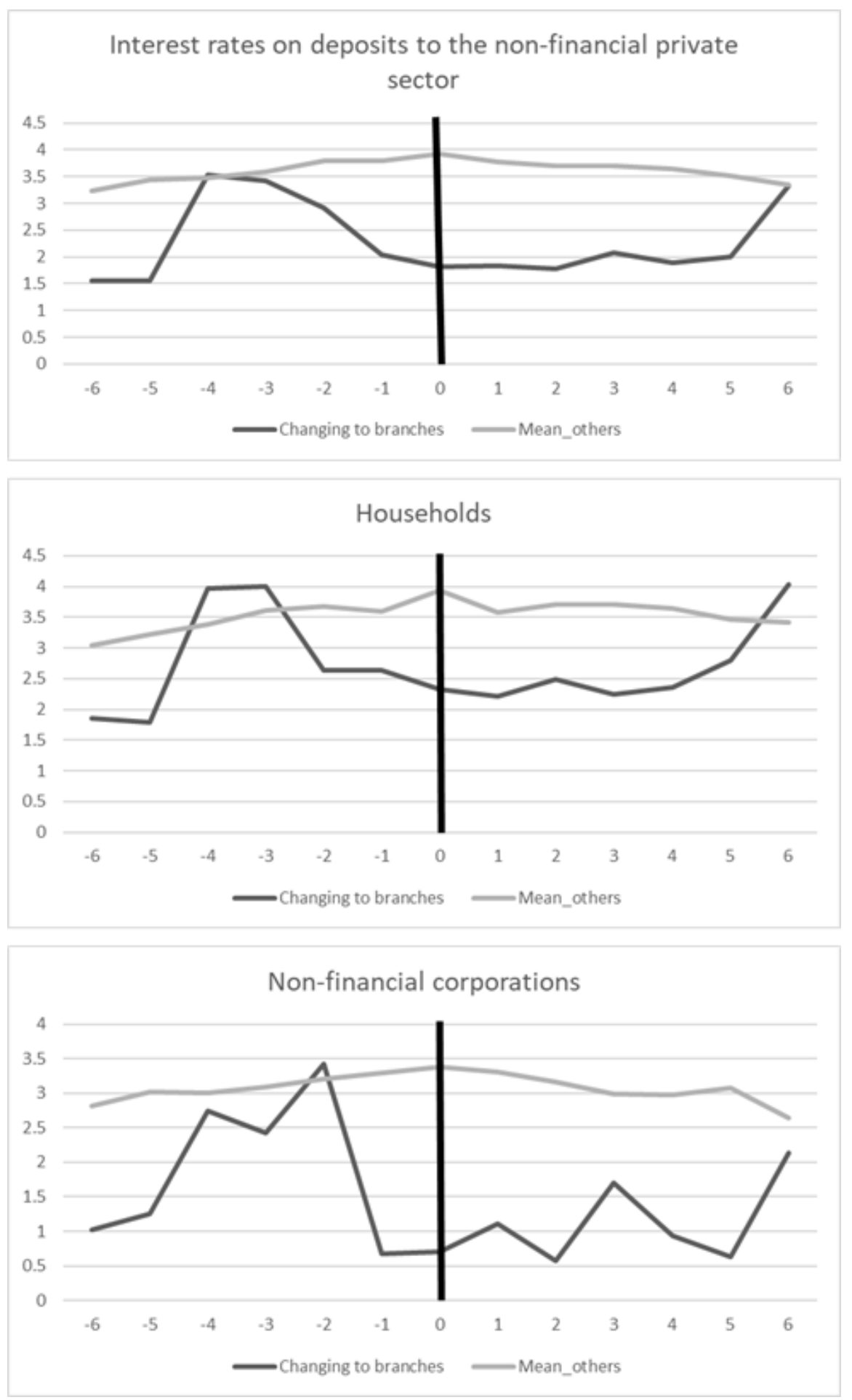

Figure 3: Interest rates on bank deposits - effects from changing to branches 


\section{Appendix:}

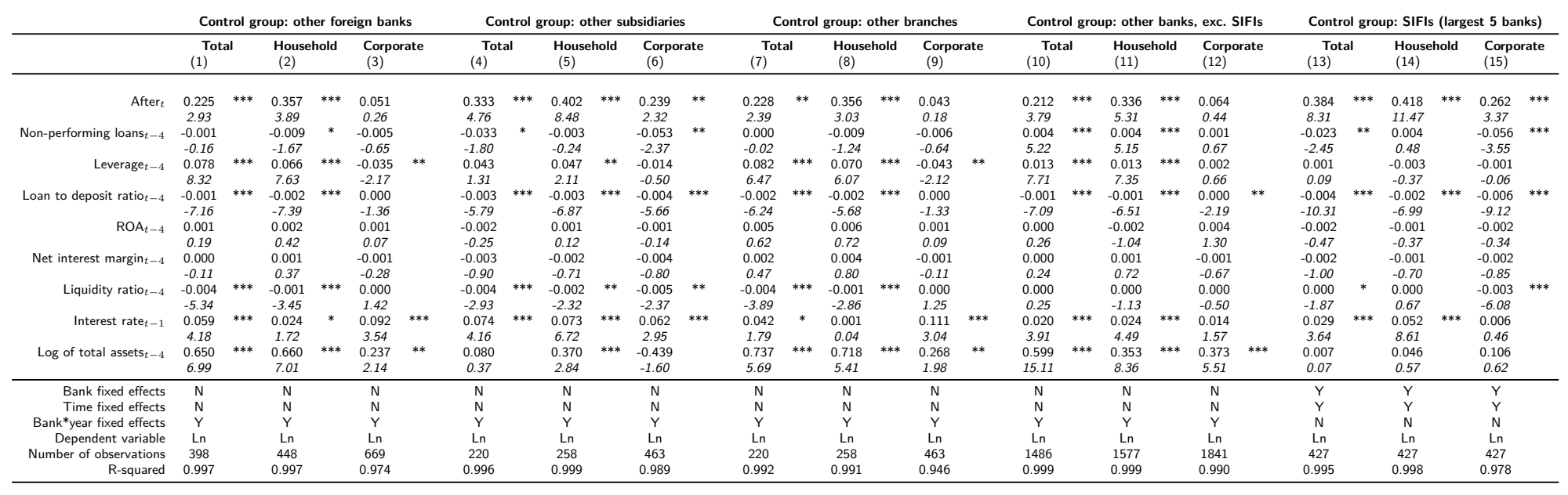

Table A.1. Exploring the transformation of foreign subsidiaries in branches - other control groups

Notes: T-stats reported in italics and standard errors clustered by bank. Explanatory variables lagged by one year, except for interest rates (lagged by one quarter). Corporate deposits refer to deposits from non-financial corporations. Leverage is defined as equity as a percentage of total assets. ROA computed as net profits as a \% of total assets and net interest margin computed as \% of total assets. The liquidity ratio is defined as liquid assets as a percentage of interbank liabilities. The total capital ratio is the regulatory capital ratio and is not available for branches from EU countries. ${ }^{* * *}$ significant at $1 \%,{ }^{* *}$ significant at $5 \%$, *significant at $10 \%$ 


\section{Working Papers}

\section{7}

1|17 The diffusion of knowledge via managers' mobility

Giordano Mion | Luca David Opromolla | Alessandro Sforza

2|17 Upward nominal wage rigidity

Paulo Guimarães | Fernando Martins | Pedro Portugal

3|17 Zooming the ins and outs of the U.S. unemployment

Pedro Portugal | António Rua

4|17 Labor market imperfections and the firm's wage setting policy

Sónia Félix | Pedro Portugal

5|17 International banking and cross-border effects of regulation: lessons from Portugal

Diana Bonfim | Sónia Costa

6|17 Disentangling the channels from birthdate to educational attainment

Luís Martins | Manuel Coutinho Pereira

7|17 Who's who in global value chains? A weighted network approach

João Amador | Sónia Cabral | Rossana Mastrandrea | Franco Ruzzenenti

8|17 Lending relationships and the real economy: evidence in the context of the euro area sovereign debt crisis

Luciana Barbosa
9|17 Impact of uncertainty measures on the Portuguese economy

Cristina Manteu | Sara Serra

10|17 Modelling currency demand in a small open economy within a monetary union

António Rua

11|17 Boom, slump, sudden stops, recovery, and policy options. Portugal and the Euro Olivier Blanchard | Pedro Portugal

12|17 Inefficiency distribution of the European Banking System

João Oliveira

13|17 Banks' liquidity management and systemic risk

Luca G. Deidda | Ettore Panetti

14|17 Entrepreneurial risk and diversification through trade

Federico Esposito

15|17 The portuguese post-2008 period: a narrative from an estimated DSGE model

Paulo Júlio | José R. Maria

16|17 A theory of government bailouts in a heterogeneous banking system

Filomena Garcia | Ettore Panetti

17|17 Goods and factor market integration: a quantitative assessment of the EU enlargement FLorenzo Caliendo | Luca David Opromolla | Fernando Parro | Alessandro Sforza 


\section{8}

1|18 Calibration and the estimation of macroeconomic models

Nikolay Iskrev

2|18 Are asset price data informative about news shocks? A DSGE perspective

Nikolay Iskrey

3|18 Sub-optimality of the friedman rule with distorting taxes

Bernardino Adão | André C. Silva

4|18 The effect of firm cash holdings on monetary policy

Bernardino Adão | André C. Silva

5|18 The returns to schooling unveiled Ana Rute Cardoso | Paulo Guimarães | Pedro Portugal | Hugo Reis

$6 \mid 18$ Real effects of financial distress: the role of heterogeneity

Francisco Buera | Sudipto Karmakar

7|18 Did recent reforms facilitate EU labour market adjustment? Firm level evidence Mario Izquierdo | Theodora Kosma | Ana Lamo | Fernando Martins | Simon Savsek

$8 \mid 18$ Flexible wage components as a source of wage adaptability to shocks: evidence from European firms, 2010-2013

Jan Babecký | Clémence Berson | Ludmila Fadejeva | Ana Lamo | Petra Marotzke | Fernando Martins | Pawel Strzelecki

9|18 The effects of official and unofficial information on tax compliance

Filomena Garcia | Luca David Opromolla Andrea Vezulli | Rafael Marques
10|18 International trade in services: evidence for portuguese firms

João Amador | Sónia Cabral | Birgitte Ringstad

11|18 Fear the walking dead: zombie firms, spillovers and exit barriers

Ana Fontoura Gouveia | Christian Osterhold

12|18 Collateral Damage? Labour Market Effects of Competing with China - at Home and Abroad

Sónia Cabral | Pedro S. Martins | João Pereira dos Santos | Mariana Tavares

13|18 An integrated financial amplifier: The role of defaulted loans and occasionally binding constraints in output fluctuations

Paulo Júlio | José R. Maria

14|18 Structural Changes in the Duration of Bull Markets and Business Cycle Dynamics

João Cruz | João Nicolau | Paulo M.M. Rodrigues

15|18 Cross-border spillovers of monetary policy: what changes during a financial crisis?

Luciana Barbosa | Diana Bonfim | Sónia Costa | Mary Everett

16|18 When losses turn into loans: the cost of undercapitalized banks

Laura Blattner | Luísa Farinha | Francisca Rebelo

17|18 Testing the fractionally integrated hypothesis using M estimation: With an application to stock market volatility

Matei Demetrescu | Paulo M. M. Rodrigues | Antonio Rubia 
18|18 Every cloud has a silver lining: Micro-level evidence on the cleansing effects of the Portuguese financial crisis

Daniel A. Dias | Carlos Robalo Marques

19|18 To ask or not to ask? Collateral versus screening in lending relationships

Hans Degryse | Artashes Karapetyan | Sudipto Karmakar

$20 \mid 18$ Thirty years of economic growth in Africa João Amador | António R. dos Santos

21|18 CEO performance in severe crises: the role of newcomers

Sharmin Sazedj | João Amador | José Tavares

22|18 A general equilibrium theory of occupational choice under optimistic beliefs about entrepreneurial ability Michele Dell'Era | Luca David Opromolla | Luís Santos-Pinto
23|18 Exploring the implications of different loanto-value macroprudential policy designs Rita Basto | Sandra Gomes | Diana Lima

24|18 Bank shocks and firm performance: new evidence from the sovereign debt crisis Luísa Farinha | Marina-Eliza Spaliara | Serafem Tsoukas

25|18 Bank credit allocation and productivity: stylised facts for Portugal Nuno Azevedo | Márcio Mateus | Álvaro Pina

26|18 Does domestic demand matter for firms' exports?

Paulo Soares Esteves | Miguel Portela | António Rua

27|18 Credit Subsidies Isabel Correia | Fiorella De Fiore | Pedro Teles | Oreste Tristani 


\section{9}

1|19 The transmission of unconventional monetary policy to bank credit supply: evidence from the TLTRO

António Afonso | Joana Sousa-Leite

2|19 How responsive are wages to demand within the firm? Evidence from idiosyncratic export demand shocks

Andrew Garin | Filipe Silvério

3|19 Vocational high school graduate wage gap: the role of cognitive skills and firms Joop Hartog | Pedro Raposo | Hugo Reis

4|19 What is the Impact of Increased Business Competition?

Sónia Félix | Chiara Maggi

5|19 Modelling the Demand for Euro Banknotes António Rua

6|19 Testing for Episodic Predictability in Stock Returns

Matei Demetrescu | Iliyan Georgiev Paulo M. M. Rodrigues | A. M. Robert Taylor

7|19 The new ESCB methodology for the calculation of cyclically adjusted budget balances: an application to the Portuguese case Cláudia Braz | Maria Manuel Campos Sharmin Sazed

8|19 Into the heterogeneities in the Portuguese labour market: an empirical assessment Fernando Martins | Domingos Seward

9|19 A reexamination of inflation persistence dynamics in OECD countries: A new approach

Gabriel Zsurkis | João Nicolau | Paulo M. M. Rodrigues
10|19 Euro area fiscal policy changes: stylised features of the past two decades Cláudia Braz | Nicolas Carnots

11|19 The Neutrality of Nominal Rates: How Long is the Long Run?

João Valle e Azevedo | João Ritto | Pedro Teles

12|19 Testing for breaks in the cointegrating relationship: on the stability of government bond markets' equilibrium

Paulo M. M. Rodrigues | Philipp Sibbertsen Michelle Voges

13|19 Monthly Forecasting of GDP with Mixed Frequency MultivariateSingular Spectrum Analysis

Hossein Hassani | António Rua | Emmanuel Sirimal Silva | Dimitrios Thomakos

14|19 ECB, BoE and Fed Monetary-Policy announcements: price and volume effects on European securities markets

Eurico Ferreira | Ana Paula Serra

15|19 The financial channels of labor rigidities: evidence from Portugal

Edoardo M. Acabbi | Ettore Panetti | Alessandro Sforza

16|19 Sovereign exposures in the Portuguese banking system: determinants and dynamics

Maria Manuel Campos | Ana Rita Mateus | Álvaro Pina

17|19 Time vs. Risk Preferences, Bank Liquidity Provision and Financial Fragility

Ettore Panetti 
18|19 Trends and cycles under changing economic conditions

Cláudia Duarte | José R. Maria | Sharmin Sazedj

19|19 Bank funding and the survival of start-ups Luísa Farinha | Sónia Félix | João A. C. Santos

\section{0}

1|20 On-site inspecting zombie lending Diana Bonfim | Geraldo Cerqueiro | Hans Degryse | Steven Ongena

2|20 Labor earnings dynamics in a developing economy with a large informal sector

Diego B. P. Gomes | Felipe S. Iachan | Cezar Santos

3|20 Endogenous growth and monetary policy: how do interest-rate feedback rules shape nominal and real transitional dynamics?

Pedro Mazeda Gil | Gustavo Iglésias

4|20 Types of International Traders and the Network of Capital Participations

João Amador | Sónia Cabral | Birgitte Ringstad

5|20 Forecasting tourism with targeted predictors in a data-rich environment

Nuno Lourenço | Carlos Melo Gouveia | António Rua

6|20 The expected time to cross a threshold and its determinants: A simple and flexible framework

Gabriel Zsurkis | João Nicolau | Paulo M. M. Rodrigues
20|19 From micro to macro: a note on the analysis of aggregate productivity dynamics using firm-level data Daniel A. Dias | Carlos Robalo Marques

21|19 Tighter credit and consumer bankruptcy insurance

António Antunes | Tiago Cavalcanti | Caterina Mendicino | Marcel Peruffo | Anne Villamil

7|20 A non-hierarchical dynamic factor model for three-way data

Francisco Dias | Maximiano Pinheiro | António Rua

8|20 Measuring wage inequality under right censoring

João Nicolau | Pedro Raposo | Paulo M. M. Rodrigues

9|20 Intergenerational wealth inequality: the role of demographics

António Antunes | Valerio Ercolani

10|20 Banks' complexity and risk: agency problems and diversification benefits

Diana Bonfim | Sónia Felix

11|20 The importance of deposit insurance credibility

Diana Bonfim | João A. C. Santos 
